IZA DP No. 8851

Impacts of Informal Caregiving on Caregiver

Employment, Health, and Family

Jan Michael Bauer

Alfonso Sousa-Poza

February 2015 


\title{
Impacts of Informal Caregiving on Caregiver Employment, Health, and Family
}

\author{
Jan Michael Bauer \\ University of Hohenheim \\ Alfonso Sousa-Poza \\ University of Hohenheim \\ and IZA
}

\section{Discussion Paper No. 8851 \\ February 2015}

\author{
IZA \\ P.O. Box 7240 \\ 53072 Bonn \\ Germany \\ Phone: +49-228-3894-0 \\ Fax: +49-228-3894-180 \\ E-mail: iza@iza.org
}

\begin{abstract}
Any opinions expressed here are those of the author(s) and not those of IZA. Research published in this series may include views on policy, but the institute itself takes no institutional policy positions. The IZA research network is committed to the IZA Guiding Principles of Research Integrity.

The Institute for the Study of Labor (IZA) in Bonn is a local and virtual international research center and a place of communication between science, politics and business. IZA is an independent nonprofit organization supported by Deutsche Post Foundation. The center is associated with the University of Bonn and offers a stimulating research environment through its international network, workshops and conferences, data service, project support, research visits and doctoral program. IZA engages in (i) original and internationally competitive research in all fields of labor economics, (ii) development of policy concepts, and (iii) dissemination of research results and concepts to the interested public.
\end{abstract}

IZA Discussion Papers often represent preliminary work and are circulated to encourage discussion. Citation of such a paper should account for its provisional character. A revised version may be available directly from the author. 
IZA Discussion Paper No. 8851

February 2015

\section{ABSTRACT \\ Impacts of Informal Caregiving on Caregiver Employment, Health, and Family}

As the aging population increases, the demand for informal caregiving is becoming an ever more important concern for researchers and policy-makers alike. To shed light on the implications of informal caregiving, this paper reviews current research on its impact on three areas of caregivers' lives: employment, health, and family. Because the literature is inherently interdisciplinary, the research designs, sampling procedures, and statistical methods used are heterogeneous. Nevertheless, we are still able to draw several conclusions: first, despite the prevalence of informal caregiving and its primary association with lower levels of employment, the affected labor force is seemingly small. Second, such caregiving tends to lower the quality of the caregiver's psychological health, which also has a negative impact on physical health outcomes. Third, the implications for family life remain under investigated. The research findings also differ strongly among subgroups, although they do suggest that female, spousal, and intense caregivers tend to be the most affected by caregiving.

JEL Classification: E26, J14, J46

Keywords: informal care, employment, work hours, health, review

Corresponding author:

Jan Michael Bauer

Institute for Health Care \& Public Management

University of Hohenheim

Fruwirthstr. 48

70599 Stuttgart

Germany

E-mail: jbauer@uni-hohenheim.de

* Forthcoming in Journal of Population Ageing. We would like to thank three anonymous reviewers for valuable comments. This work is part of the project "Ageing, Work \& Health" which is funded by the Pfizer-Stiftung fuer Geriatrie und Altersforschung. 


\section{Introduction}

Not only have increasing life expectancy and lower fertility rates increased the elderly dependency ratio in most industrialized countries (Bettio \& Verashchagina 2010), but a higher share of elderly, being associated with worse health, inherently implies a higher demand for care (Polder et al. 2002, Schwarzkopf et al. 2012). In most countries, a major share of such care is provided informally, meaning that it is not reflected in social statistics (Bettio \& Verashchagina 2010, Kemper et al. 2005). Yet even though informal caregivers work mostly without payment, care provision can still come at a certain cost: in particular, it is timeconsuming, mentally stressful, and physically exhausting, which can negatively affect the caregiver's career and health. The main focus of this paper, therefore, is the effect of informal care provision in three different domains of the caregiver's life: employment, health, and family. In terms of the first, caregiving is often a full-time job, which reduces its compatibility with full-time employment. Hence, we examine the impact of caregiving on employment at both the extensive and intensive margin. As regards the second, caregiving can be a mentally and physically burdening task that negatively affects caregiver health. Because the body of literature on such effects is large, however, we review the research on psychological and physical health separately. For effects on the family, we concentrate on the literature that addresses caregivers' family dynamics and living arrangements, because caregiving is constantly present within the household and therefore affects the family’s daily living.

Although committing to a caregiver role is an individual decision, the welfare support needed by elderly for whom no informal care is available is also a matter for policy-makers. Yet economic analyses point to a complex problem set; in particular, different countries have selected different solutions, and it remains unclear whether it is formal or informal care expansion that would best meet rising demand. On the one hand, fostering informal care ties labor to households in which productivity may be lower than in the labor market. On the other, not only is the expansion of formal care support expensive and unpopular among care 
recipients, but theoretically, it remains unclear whether formal and informal care are actually substitutes. Formal care does, however, allow caregivers to better manage their domestic care arrangements and may reduce the need for placement in nursing homes.

This review, based on the most relevant literature identified in a web search on caregiving effects, ${ }^{1}$ focuses on the outcomes of elderly caregiving on the caregiver from primarily an economic perspective. With a few noteworthy exceptions, ${ }^{2}$ it includes only empirical work published in peer-reviewed journals between 2000 and 2013. However, because the effects of caregiving on health outcomes are also extensively analyzed in gerontology, psychology, and medicine, when assessing the health effects of caregiving, we refer to several meta-studies and literature reviews from these disciplines.

The paper is structured as follows: After providing an overview of the prevalence and measurement of informal care, as well as the institutional background, we focus on the impact of caregiving on the caregiver. From this discussion, we draw several conclusions, which are elaborated in the final section.

\section{Background}

Despite widespread agreement that family members are the backbone of a society's care supply $^{3}$, exact numbers on informal caregiving are unavailable because two vital elements for gauging them are lacking, an official definition of informal care and official statistics on household production. Nevertheless, a report funded by the European Commission (Triantafillou et al. 2010) does identify the following characteristics as typical of informal caregivers (see also Van den Berg et al. 2004, OECD 2011): a close relationship with the care receiver, no professional training, no working contract, no equivalent pay, a wide range of

1 The literature was identified by using the following key works and their combinations in Google Scholar, Scopus, and Science Direct: "elderly care," "informal care," "aged care," "employment," "labor force participation," "work," "work hours," "wage," "health,” "burden,” "well-being,” "family,” and "relationship." We also screened the references for any important omissions.

2 Because the research on implications for the family was sparse, we extended the time span for this topic to a few literature reviews published prior to 2000.

3 See Albertini et al. (2007) for a theoretical and empirical discussion of European family transfers. 
care giving duties, no official hours (never really off duty), and no entitlement to social rights.

\section{Prevalence of Informal Care}

Policy-makers need to know the prevalence and value of informal work because changes in informal supply are linked to public welfare and influence the social security balance sheet. Although officials in countries that publicly support informal care (e.g., Germany) can gather data about care recipients from their long-term care insurance (LTCI) ${ }^{4}$ provider, these data focus on care recipients (not caregivers) and exclude those who do not apply for benefits or fit none of the entitlement requirements. As a result, most information on the magnitude of informal care ${ }^{5}$ is derived from surveys, ${ }^{6}$ often in the form of interviews with representative subsamples. In 2011, the OECD released a report on long-term care that examined the challenges for countries facing growth in care needs. With an almost $10 \%$ share of people over 80 by 2050, demand is estimated to be largest in OECD countries. However, the care regimes differ substantially between nations: for example, while only $8 \%$ of the population in Sweden reports being involved in informal caregiving (providing help with activities of daily living), the share in Italy is reportedly twice as high.

In a report for the European Commission, Bettio and Verashchagina (2010) use the Survey on Health, Ageing and Retirement in Europe (SHARE) to document the extent of informal care in the European Union. They report that in 2007, approximately 60\% of the 20.7 million dependent elderly in the EU received informal or no care, thereby highlighting that "informal care givers — family and friends—remain the most important group of providers [in the EU]” (p. 77). Moreover, differences in the prevalence of informal care across Europe are large, with certain Eastern European countries relying nearly exclusively on informal care while countries like France and Belgium have a much larger share of formal care. For the United

4 In 2011, 2.5 million people received benefits from the German LTCI, which equals about 3.1\% of the population.

5 Such research commonly employs one of two survey methods: (i) diary methods, considered the gold standard because they bring in the most accurate information about time use, and (ii) recall methods, which are more widely used because they are easier and cheaper to carry out (Van den Berg et al. 2004).

6 For example, the 2001 UK census reported 5.2 million informal caregivers in England and Wales, while the 2000 General Household Survey identified 6.8 million for the entire UK (Heitmueller 2007). 
States, precise diary information from the American Time Use Survey suggests that in 20112012, 39.6 million people in the civilian (noninstitutional) U.S. population aged 15 and over engaged in elderly care provision (Bureau of Labor Statistics 2013).

\section{Institutional Differences}

The variation in informal care among countries can be accounted for, at least to some extent, by differences in the availability of public support and possible alternatives, which determine the opportunity costs of becoming a caregiver. In most OECD countries, caregivers are entitled to leave work for a limited amount of time, but the absence granted from work varies and only some countries provide paid leave. Even when paid leave is provided, however, it tends to be short, usually less than a month and rarely as long as the 12 months allowed in Belgium. The amount of such compensation also varies; Scandinavian countries, for example, offer between $40 \%$ and $100 \%$ of the caregiver's original wage. With regard to regulation of unpaid leave, countries can be grouped into two clusters (OECD 2011): countries in one cluster, including Belgium, France, Spain, and Ireland, allow absence from work for several years; those in the other (which includes mostly English-speaking countries) only grants shorter leaves of up to three months. Yet even though such regulations exist, data from the 2004 European Establishment Survey on Working Time and Work-Life Balance shows that the use of these opportunities is still limited (OECD 2011). That is, although care leave is available to roughly one third of employees in Europe, with lower shares for Canada and Japan, its use differs among sectors, being more common in the public sector and in large companies.

Another incentive used to promote care in the home to avoid hospitalization is financial transfers made either to the care receivers themselves or to the informal caregivers. Entitlement to such benefits, however, also differs across countries: in Scandinavia, for instance, caregivers receive a remuneration that can vary with care needs. However, even though the compensation in Sweden, for example, is fairly generous, the regulations for 
granting such compensation are very restrictive to minimize disincentives to work among certain low-wage earners. These disincentives are even greater for caregivers living in English-speaking countries where benefits are means tested. If the entitlement to benefits requires that caregivers earn below a certain threshold, it reduces the opportunity costs for dropping out of the labor force or reducing working hours. Providing cash benefits directly to the care receiver, on the other hand, avoids many administrative issues because the care receivers decide how the money will be used. Such direct payments, which allow care receivers a very flexible use of money to meet their individual needs, are used by three quarters of OECD countries. However, this payment scheme, although intended to promote individual responsibility, carries other risks to family arrangements. For example, introducing such financial incentives into an altruistically motivated care relationship could promote monetary dependency by caregivers and thus decrease intrinsic motivation.

In Germany, instead of cash transfers, families can also receive benefits in kind. For instance, depending on the intensity of the care needs, families can get support from private formal care professionals who perform certain care tasks in the domestic environment. Such care support is often used when the care burden exceeds the informal caregiver's capability. When care needs become so intense that the household is unable to ensure appropriate accommodations, institutionalization may become unavoidable. In this case, some countries provide financial support by paying a certain share of the monthly expenses for the nursing home.

In general, however, public support-whether in cash or kind-affects families' willingness to provide informal care, a link than can move in either of two directions. On the one hand, formal care can complement informal care, especially when the informal caregiver is employed, while cash benefits allow the caregiver to reduce employment to provide sufficient care and keep income at an acceptable level. Formal support may also reduce the care burden to a compatible level, thereby enabling the employee to maintain the informal 
care arrangement. On the other hand, when formal care substitutes for informal care, an increase in its supply decreases the time devoted to informal care.

Several empirical studies find evidence for such substitution effects (Clark et al. 2001, Van Houtven \& Norton 2004, Bolin et al. 2008a, Pickard 2012), which, even though mostly small, are characterized by a clear negative correlation between informal and form care alternatives in both the U.S. and Europe. Bonsang (2009), for example, finds a negative correlation between hours of low-skilled formal care (e.g., housework, shopping, and minor care tasks) and informal care, while high-skill tasks (e.g., nursing care) for severely impaired elderly parents complement informal care weakly. These results, which seem consistent among the nine European countries studied, $^{7}$ suggest that in severe care situations, a combination of informal and formal domestic care can avoid the need for nursing home placement.

\section{Value of Informal Care}

Because informal care is, by its very nature, not handled by the market, it has no price tag, making a proper comparison with formal care only possible to a certain extent. Nonetheless, several studies have tried to measure and valuate informal care monetarily using various methods to estimate an adequate price for care hours. ${ }^{8}$ For the U.S., for example, Arno et al. (1999) investigate the prevalence of informal care and the amount of money needed to substitute all informal care with formal alternatives. For their approximation, they use two data sets from the mid-1980s and assume constant caregiving ratios for the same cohorts until 1997. The hours of caring are taken from the National Family Caregiving Survey, which suggests an average of 17.9 hours per week. Setting the valuing wage at $\$ 8.18$, the mean of

\footnotetext{
Austria, Belgium, Germany, Denmark, France, Italy, the Netherlands, Spain, and Sweden.

The three commonest methods for valuing the amount of informal care are (i) using the caregiver's opportunity to value the time that could be used to supply labor elsewhere, (ii) valuing the time provided according to possible market substitutes (e.g., nurses or unskilled workers), and (iii) using the caregivers' reported well-being and valuing the mean time spent on caregiving based on the rise in income necessary to keep caregiver well-being constant when providing one additional hour of care (Van den Berg \& Ferrer-i Carbonell 2007). The second method, often termed the "proxy good method," is the most widely used because of its ease of application (for further information, see Van den Berg et al. 2004, 2005, Van den Berg \& Spauwen 2006, Sousa-Poza et al. 2001).
} 
the minimum and average wages of home health aides, they calculate the value of informal caregiving as $\$ 198$ billion, which is equivalent to $18 \%$ of total U.S. health care expenditures at that time. A similar study on dementia caregiving, however, calculates a 1993 value of only \$18 billion (Langa et al. 2001).

In a 2006 measure of the magnitude of informal care in Germany, Schneider (2006) estimates that 7\% (4.8 million) of the over-16 German population are care providers, which corresponds to 4.9 billion hours of informal care. Substituting for this informal labor would require over 3 million full-time employees and, depending on wages, between $€ 30$ and $€ 60$ billion in salary. For Dutch caregivers, Van den Berg and Ferrer-i-Carbonell (2007) estimate the monetary compensation for one additional hour that would keep caregiver wellbeing constant. Based on the means of caring hours (49 hours per week) and income (€1,665 net household income per month), they identify adequate compensation as between $€ 7$ and $€ 10$ for each additional hour of care, ${ }^{9}$ which is slightly lower than most Dutch market proxies.

\section{Implications for Caregivers}

Even though many care arrangements involve informal support, care provision is often a burden, so households must find an arrangement that takes into account several factors. First, care recipients usually prefer to stay in their own homes, which requires either family members able and willing to provide informal care or formal care support that is both accessible and affordable. In deciding between the two, potential caregivers must be aware that caregiving is a major responsibility that is time consuming and stressful. In addition, because the need for care occurs primarily at an older age, spouses are likely to be older themselves, which reduces their capabilities. Children, on the other hand, being more likely to be employed or have other obligations within their own household, face higher opportunity costs. Hence, choosing either arrangement always involves trade-offs for the caregiver.

\footnotetext{
9 Price varies based on the family relationship between care recipient and caregiver, with family caregiving
} requiring higher monetary compensation. 
In the following sections, we review the relevant literature with a focus on the implications for caregiver employment, health, and family, not only in terms of individual outcomes but also from a policy perspective. Undoubtedly, if dignified aging is to be ensured, the increased demand for caregiving must be met with a satisfactory supply, yet formal care is expensive and public money short. Fostering informal care arrangements, therefore, seems tempting because it saves direct costs in professional care services and can postpone expensive hospitalization. These savings, however, may be offset by such indirect costs as reduced employment, possible loss in human capital, and higher health care expenditures for caregivers.

\section{Employment}

When potential caregivers are of working age, the time used for informal care competes with that for paid work, meaning that the opportunity costs of informal care are often associated with paid employment ${ }^{10}$ (Becker 1965). We therefore examine the evidence of a link between informal care and employment decisions and strive to identify which characteristics of the care arrangement matter and to what extent informal care affects caregiver employment. In particular, caregiving is still too often seen as "women’s work," meaning that recent political efforts to increase female labor force participation (e.g., European Commission 2011) are likely to fail for women tied to a caregiver role. Conversely, there are rising concerns that increasing female labor force participation could reduce the willing supply of informal care. If a smaller supply of informal care does indeed imply a greater demand for formal care, then understanding the link between care and work is extremely important for forecasting future care needs.

Research into these issues has been greatly facilitated by the growing availability of longitudinal data and the development of more sophisticated statistical methods. In particular, these latter are greatly aiding the determination of causality, which although not taken into

10 For extensions with other time-allocation categories, see Gronan (1977); for a summary of all costs for adult caregivers, see Keating et al. (2014). 
account by all the studies reviewed here (see table 1), is always an important consideration. From the causal perspective, any negative care-work association can be explained in two ways: first, care is time consuming, so combining it with regular employment is difficult; caregivers must reduce work hours or even quit their jobs to provide sufficient care to the individual in need. Second, because unemployed or part-time workers have more time, they are more likely to become caregivers. Not only are these two lines of causality equally plausible, they are not mutually exclusive and can even occur simultaneously (Michaud et al. 2010). However, several recent studies find little evidence for an endogenous caregiving decision and thus treat caregiving as exogenous, particularly when controlling for unobserved individual characteristics in panel data (see Bolin et al. 2008b, Ciani 2012, Meng 2012, Van Houtven et al. 2013, Nguyen \& Connelly 2014). The instruments used in such research, however, often measure the health of potential care receivers, which should exogenously increase the demand for caregiving. These instruments are criticized on the grounds that a dummy variable or metric measurement of care hours is unable to sufficiently capture a heterogeneous care task. Hassink and Van den Berg (2011), for instance, argue that ignoring the fact that some care task are "time-bounded" while others can be shifted from one day to another can affect the exclusion restriction in the instrumented regressions and thus provide biased estimates. Doubts about the use of care needs as an instrument have already been raised by Heitmueller (2007). For their cross-sectional data the IV estimates are almost 10 times larger than the OLS results, which are supposed to overestimate the effect of caregiving.

\section{Work Status}

Although a negative association between informal care and work is supported by the theory of opportunity costs and time allocation within households (see Becker 1965, Pezzin et al. 1996), several studies refute the existence of such a link, reporting only a small or no correlation between the two. For example, Lilly et al.'s (2007) review of 34 articles on 
caregiving's effects on labor force participation published between 1986 and 2006 finds no convincing evidence that caregivers show generally lower levels of employment. One explanation for such a weak informal care-work relation is caregivers' low attachment to the labor force, which implies that they would be unlikely to increase their participation in paid employment even without the caregiving burden. Evidence for such selection is provided by several studies: Dautzenberg et al. (2000), for example, although they use an admittedly small sample, find that unemployed daughters who live close by are most likely to become caregivers. Carmichael et al. (2010) provide evidence that future caregivers, ${ }^{11}$ although they share similarities with actual caregivers, differ significantly from those who have never taken on that role. For example, male (female) future caregivers have a 6\% (5\%) lower employment rate and are more likely to work in unskilled (noncareer track) occupations. In support of this notion, Michaud et al. (2010), using data from the British Household Panel Survey (BHPS), show that current employment reduces the probability of becoming a caregiver in the future. Results from Dutch data also suggest that employment in the previous year reduces the probability of caregiving by 2.4\% (Moscarola 2010). Berecki-Gisolf et al. (2008), however, can find no systematic difference between Australian female future caregivers in their 50s and their noncaregiver peers nor any significant effect of current employment on the likelihood of providing care.

Nevertheless, as Leigh (2010) emphasizes, selection may take place on unobserved characteristics, including personality traits and general labor force attachment, and can change the estimates greatly. Using panel data from Australia, he finds that accounting for individual fixed-effects reduces the strong negative coefficients for the link between caregiving and labor force participation from -20 to $-28 \%$ to $4-6 \%$ (also see Heitmueller 2007). Likewise, accounting for individual fixed-effects and ruling out endogeneity in a sample from the U.S. Health and Retirement Survey (HRS) results in no significant effect of being a caregiver on

\footnotetext{
${ }^{11}$ Individuals in year $t-1$ before they become actual caregivers.
} 
employment probability (Van Houtven et al. 2013). For Germany, Meng (2012), in an analysis of the effect of care hours in seven waves of the German Socio Economic Panel , finds no reduction in labor force participation. However, although Viitanen’s (2010) analysis of the European Community Household Panel (ECHP) initially identifies Germany as the only one among 13 European countries that has a significant caregiving-work relation, once the state dependency of labor force participation and individual fixed-effects are controlled for, this negative impact falls to only 0.3 percentage points. For Canada, Lilly et al. (2010) obtain only small, slightly significant effects for their male sample and conclude that the net effect of caregiving on employment is not significant.

Even though these effects remain small, however, the majority of studies do provide some evidence that caregivers are less likely to have a paid job (Carmichael \& Charles 2003, Bittman et al. 2007, Berecki-Gisolf et al. 2008, Bolin et al. 2008b, Carmichael et al. 2010, Lilly et al. 2010, Nguyen \& Connelly 2014). For example, Bolin et al. (2008b), using data from SHARE, identify a $10 \%$ increase in care hours associated with a $3.7 \%$ lower employment probability. In terms of comparability, the marginal effect from a random-effects probit in Kotsadam's (2011) analysis of ECHP data indicates that lower employment probability for caregivers varies between countries, with a $5 \%$ lower probability for the full European sample. An analysis of the same data, using a sample of men aged 40-64 and women aged 40-59, shows a significant but small effect on labor force participation, with a causal effect of 1\% (2\%) for northern (southern) countries in Europe (Ciani 2012). However, a simultaneously estimated care-work equation for a Dutch subsample of the ECHP finds the caregiving probability to be $5.8 \%$ lower once the state dependency of employment is accounted for (Moscarola 2010).

Spiess and Schneider (2003), on identifying an asymmetric response in which entering the caregiver role reduces labor force participation but leaving or reducing it results in no participation adjustment, attribute it to the fact that for the 45- to 59-year-old women sampled, 
the years to retirement are few. Wakabayashi and Donato (2005) identify a similar dynamic in their female sample—significantly reduced labor force participation on entering the caregiver role but no reentry after leaving it. This finding is supported by Van Houvten et al. (2013), who demonstrate a significantly higher probability of being retired among caregiving women, while employment probabilities remain unaffected. Such an asymmetric response might be associated with depreciation of skills: in interviews, caregivers have reported being unable to reenter employment after a long duration of caring because their job specific knowledge was outdated (Carmichael et al. 2008).

\section{Work Hours}

The research results on the extensive margin remain rather small, possibly because of a flexible working environment that allows caregivers to adjust their work hours rather than leaving the labor force completely. There is strong evidence, however, that caregivers are more likely to work fewer hours than noncaregivers (Lilly et al. 2007), a finding supported by multiple recent findings of caregivers adjusting their work hours (e.g., Bittman et al. 2007, Berecki-Gisolf et al. 2008, Bolin et al. 2008b, Leigh 2010, Kotsadam 2011, Meng 2012, Van Houtven et al. 2013). In Europe, for instance, Bolin et al. (2008b) find a working-caring-time elasticity for a SHARE sample of -0.26 when informal care is treated as exogenous. This rather inelastic response on working hours is echoed by Kotsadam (2011), who finds that caregivers have 2-3\% lower working hours for a full European sample compared to noncaregivers. Meng (2012), however, identifies only a small effect for Germany: providing 10 hours more care per week is associated with a reduction of 48 (35) minutes for men (women) in weekly working time. Leigh (2010) obtains mixed results depending on the definition of caregiver. For instance, the effect of caregiving on work time is significant in a group of individuals that self-classify as caregivers but not in a group defined by whether or not they receive public care allowances. Similarly, in their analysis for Canada, Lilly et al. (2010) find that once they adjust for potential indirect effects from wage differences, 
primary caregiving has no negative effect on the log of weekly labor force hours, but when they increase the threshold of care duty to 15-20 hours per week, a negative link emerges.

Few recent studies find an overall strong link on working hours, but should be treated with caution. For instance, Bittman et al. (2007) observe that about 20\% of full-time working women in Australia will give up full-time for part-time work after taking on care duties. However, this result is based upon simple correlation, which might overestimate the casual effect of care on employment.

That accounting for endogeneity not necessarily reduces the estimates was demonstrated by Van Houtven et al. (2013), who also obtain insignificant results for caregiving's effects on work hours when treating informal care as exogenous. In their 2SLS approach, only the work hour regressions pass the endogeneity test. However, in contrast to the exogenous fixedeffects results, the instrumented care supply yields significant and substantial negative effects on work hours: caregivers who provided at least 100 hours of care over the previous two years work three hours less a week than noncaregivers. Likewise, providing care reduces the working hours of middle aged women by $41 \%$ on average, even when individual heterogeneity and endogeneity is accounted for (Johnson \& Lo Sasso 2006). In line with Heitmueller (2007), the results suggest that exogenous caregiving underestimates the effect of caregiving on labor force participation. A finding difficult to explain, particularly in models accounting for individual fixed-effects.

\section{Wages}

The opportunity costs of caregiving not only relate to time spent in paid employment but may also affect wages. For example, potential caregivers earning higher wages face higher opportunity costs for one hour of informal care. In such a case, purchasing formal care substitutes is more attractive, implying a negative correlation between time spent for informal care and wages. Caregiving might also interfere with work, leading to lower performance and fewer promotions and thus a wage penalty for caregivers. Empirical evidence on such wage 
effects also tends to be inconclusive, with some studies finding that caregivers earn lower wages (e.g., Carmichael \& Charles 2003, Wakabayashi \& Donato 2005, Bittman et al. 2007, Heitmueller \& Inglis 2007) but others identifying no or only very small effects (e.g., Bolin et al. 2008b, Lilly et al. 2010, Van Houtven et al. 2013). Carmichael and Charles (2003), for example, estimate that wages are 18\% (9\%) lower for male (female) caregivers who provide more than 10 hours of care per week. Likewise, Heitmueller and Inglis (2007), using English data to estimate the opportunity costs of caregiving in the form of wage reductions, find that caregivers earn about $6 \%$ less, with about half the reduction directly accounted for by care provision. The authors also show that this effect has increased over the years (1993-2002) and differs between genders, with women being more affected than men. Bittman et al. (2007) relate such wage effects not only to care intensity but also to care duration: whereas the income of Australian caregivers in their first two years is lower by about $\$ 10,000$ annually, the difference to noncaregiver increases to $\$ 12,000$ in the fourth year.

Because caregivers might expect future care demand to increase, Van Houtven et al. (2013) speculate that wage reductions might arise from caregivers selecting into jobs for which they are overqualified. However, these authors identify no overall negative effect on wages and only a small but significant wage reduction (3.1\%) for women providing help with chores, the least intense care arrangement in their analysis. Similarly, using data from SHARE, Bolin et al. (2008b) find that caregiving does not generally reduce wages, a result supported by Lilly et al. (2010) for Canada.

Overall, the empirical findings related to employment and wages, being sensitive to the specific care situations and caregiver subgroups, are often difficult to generalize. Most studies, for instance, take a distinct look at the caregiver's gender, relationship to the care recipient, and living arrangements. Large impacts on the caregivers’ labor force participation are mostly observed among particular at-risk groups or subsamples (see, e.g., Nguyen \& Connelly 2014). Researchers also often address other characteristics that seem to influence the 
work-care relationship, ${ }^{12}$ such as the tendency for older, white, or uneducated caregivers to suffer more in terms of career (Wakabayashi \& Donato 2005).

\section{Gender Differences}

The effect of caregiving on employment, work time, and wages often differs between men and women. For instance, Carmichael and Charles (2003) show that even though all caregivers face lower wages (cf. Heitmueller \& Inglis 2007), which reduces the likelihood of their working in a paid job (indirect effect), only women directly substitute their paid work with informal care work. The authors further report that women seem to have a weaker attachment to employment than their male counterparts. ${ }^{13}$ In support of this latter, King and Pickard (2013) find that only women are affected by becoming a caregiver: employed women who begin to provide less than 10 hours of care per week have an even higher likelihood than noncaregivers of being employed one year later. On the other hand, they also observe a negative association between becoming an intense caregiver (over 10 hours per week) and future employment. The gender-based findings reported by Van Houtven et al. (2013), however, contradict these findings. In their examination of extensive effects, they show that only men providing personal care are $2.4 \%$ less likely to work, whereas women suffer a wage penalty and reduced working hours. Nguyen and Connelly (2014), in contrast, find no gender differences, whereas Meng (2012) identifies a slightly lower reduction in work hours for female caregivers in Germany.

Because women are more frequent caregivers, provide care at higher intensity, and experience higher social pressure to provide care (Carmichael \& Charles 2003), they are of particular research interest, leading some studies to focus only on female care provision (e.g., Johnson \& Lo Sasso 2006, Kotsadam 2011, Casado-Marin et al. 2011). For instance Berecki-

\footnotetext{
${ }^{12}$ For a list of other possible mediators suggested in pre-2006 studies, see Lilly et al. (2007).

${ }^{13}$ Carmichael and Charles (2003) note that they themselves define the direction of causality in this paper arbitrarily. In particular, they assume that care choices are made exogenously and do not consider opportunity costs, although they do not rule out the possible interaction between the mutual effects of care and employment.
} 
Gisolf et al. (2008), who find that middle-aged females are twice as likely as noncaregivers to reduce their labor force participation after becoming caregivers.

\section{Importance of Residency and Intensity}

In addition to certain caregiver characteristics, the way that caregiving is defined also appears crucial. Even though the overall effect of caregiving on employment seems to be small, most studies find a relevant association between caregiving and labor force participation/wages for at least some types of care arrangement. One important characteristic related to employment decisions within caring families is residency, which Heitmueller (2007) investigates by using cross-sectional and panel data. The different estimations indicate that both co-residential and intensive care have a significant impact on employment but extra-residential care does not. These findings are confirmed by CasadoMarin et al. (2011) using eight waves of a Spanish subsample from the ECHP to show that among middle-aged women, only co-residing caregivers suffer negative effects on labor force participation. Similarly, Michaud et al. (2010), in an analysis that accounts for both timeinvariant heterogeneity and a dynamic care- employment for which causality is plausible in both directions, reveal a statistically significant correlation between a co-residential caregiver subsample and future occupation, even though they identify no overall effect.

Caregiver residency also plays a crucial role in selection into caregiving. For example, Carmichael et al. (2010) use a discrete-time logit model to show a negative link between employment, as well as higher hourly earnings, and the probability of care provision, especially in a co-residential setting. Such marked effects on the caregiver's labor force participation are not surprising given that co-residing with the care receiver often reflects high care demands (see Heitmueller 2007, Nguyen \& Connelly 2014). Hence, Lilly et al. (2007) conclude that cases of intense care are inherently related to lower labor force participation; the threshold for intense caregiving varies among studies, but points mostly to caregiving over 10 hours (King \& Pickard 2013) or 20 hours a week (Heitmueller 2007, Lilly et al. 2010). In 
fact, Carmichael et al. (2008), in their analysis of the impact of caring responsibilities on employment, conclude that those who provide care for long hours over a longer period are far more likely to adjust their job participation or leave employment completely.

Additional differences are observable for primary and secondary caregivers, with only the former showing meaningful reductions in their labor force participation. For instance, Nguyen and Connelly (2014) find an approximately 12\% lower probability for employment among Australian primary caregivers (see also, Lilly et al. 2010), a much stronger impact than for secondary caregivers. On the other hand, Lee and Tang (2013), using HRS data to assess differences in types of caregiving tasks, find that the employment probability for women providing care personal care to their parents is significantly lower, whereas the coefficient for also running errands and helping with chores (in combination with personal care) shows no effect. This finding stands contrast to Van Houtven et al.'s (2013) observation that caring for chores does reduce female wages and increases the retirement probability, while personal care has no effect.

\section{Quality of Work}

Another factor that may be negatively affected by caregiving is work quality, and not necessarily just employment status and work hours. Reid et al. (2010), for example, show that $46.3 \%$ of employed caregivers feel that their work performance is affected and about $40 \%$ of caregivers say they miss work or have had to leave suddenly because of their care responsibilities. These effects could lead to fewer promotions and may partly explain why caregivers tend to earn less. For instance, a survey among Norwegian caregivers (Gautun \& Hagen 2010) suggests that caregiving often leads to late arrival or early departure from work (16\%), the need to reschedule the work day (13\%), and/or problems concentrating during work hours (10\%). On the other hand, in terms of labor force participation, the survey also indicates that most caregivers try to combine work and care by using accumulated holidays (31\%) and flexible working hours (15\%), with only a few reducing their work hours. 
Nevertheless, although the above findings suggest a very complex interplay between caregiver, recipient, employer, and the institutional background, more recent quantitative research suggests that caregiving's impact leads to a broad spectrum of outcomes in the labor market. Ugreninov (2013), for instance, using Norwegian data, demonstrates that employees who combine full-time work with caregiving are more likely to be absent from work because of sickness.

\section{International Differences}

Finally, it must be stressed that countries differ in the assistance they provide. For example, whereas many countries provide considerable support for those needing care and their families, in the United States, such aid tends to be limited. The effects of caregiving on labor force participation even differ noticeably within continental Europe. For instance, although Bolin et al. (2008b) find no significant effect on employment for their entire European sample, they identify a lower probability of employment for men from central Europe. ${ }^{14}$ Central European caregivers of both genders also work fewer hours than those in other areas. The estimates for Nordic caregivers, in contrast, are only significant for men. The highest wage gap among the regions is observed between female caregivers in southern Europe and their male counterparts.

These variations may stem from cultural and institutional differences, including differing degrees of governmental support for caregivers in the form of such entitlements as job leave and tax cuts or benefits like cash and in kind. Families formulate their care arrangements in light of such regulations, which must therefore be considered when assessing effects on labor force participation or health. For example, the negative link found by Spiess and Schneider (2003) between starting care provision and working hours in a European sample is only significant for northern countries, whereas increasing care hours reduces working hours only in the south. The authors ascribe these differences to the more flexible work environment

\footnotetext{
${ }^{14}$ The authors divide Europe into the following three areas: (1) Nordic (Sweden and Denmark); (2) Central (Germany, France, Netherlands, Austria, and Switzerland), and (3) Southern (Spain, Italy, and Greece).
} 
and higher levels of formal support, which allow female caregivers to adjust to the care situation and find a better balance between employment and informal care. Using the same data, Kotsadam (2011) conduct separate analyses for three European areas—north, central, and south-which support the notion of a north-south gradient along which the effects of caregiving on female employment and work hours are generally smaller in the north than in the south (see also Ciani 2012). Different working environments, i.e. job options as flexible work hours, telecommuting, or compassionate care leave, affect labor force decisions even within a country: U.S. female caregiver with access to such arrangements are more likely to remain in the labor force (Pavalko \& Henderson 2006).

\section{Health}

Because informal care involves both psychological effort and a physical burden, some researchers distinguish between the psychological and physical health outcomes of caregiving, while others study both relations simultaneously (see table 2). The majority of studies focus on psychological outcomes, although they employ different, and frequently ambiguous, dependent variables. Some investigations, for example, measure the correlation between caregiving and depression symptoms, while others analyze the links with subjective well-being, burden, and other mental health measures. Informal caregiving and psychological health are related not only because the former is time-consuming and frequently difficult to combine with work and family life, but because caring for close family members in need may induce negative emotions linked to compassion and fear of loss. In addition, caregiving is a stressful task that can require great physical effort, particularly in special cases such as mentally impaired relatives who develop behavioral problems and even aggressive habits. Hence, policy-makers must be concerned not only with the self-evident interests of the individuals but also the poor caregiver health that can result from the informal care burden. This latter implies higher health care expenditures, which must be taken into account when 
promoting or supporting informal care arrangements. Poor health can also decrease caregivers' capacity for care provision, leading to low quality care or a reduced informal care supply and increasing demands for formal care.

\section{Psychological Health}

Several meta-analyses that pay particular attention to the psychological implications (e.g. Schulz et al. 1990, 1995, Pinquart \& Sörensen 2003a, 2003b, 2006, Savage \& Bailey 2004) indicate that the majority of studies find a negative association between caregiving and psychological measures. Schulz et al. (1990), for example, review 33 articles published between 1968 and 1990 in order to identify the psychiatric morbidity effects of caregiving. Most of the work reviewed assesses these psychological effects using multi-item scales that include questions about general well-being or happiness. The evidence overall suggests that caregivers tend to show an above-average level of psychiatric symptoms. In a subsequent review, Schulz et al. (1995) concentrate on 41 papers, published from 1989 to 1995, that focus on the well-being effects of caring for dementia patients, a form of care that places a high burden on the caregiver. Their general conclusion is that providing care for dementia patients leads to higher levels of depressive symptoms (see also Etters et al. 2008).

A more recent review by Pinquart and Sörensen (2003a), which covers 228 studies between 1966 and 2002, focuses on the psychological effects of elder care provision on the caregivers. These authors cluster the studies based on similar characteristics related to outcome (caregiver burden or depression), sampling (probability or convenience samples), impairment (dementia, non-dementia, or mixed patients), and the relationship to the caregiver (spouse or adult children). They find overall evidence that behavioral problems (e.g., disruptive and aggressive behavior), physical and cognitive impairment, and the time spent on caregiving place a burden on the caregiver and increase symptoms of depression, with behavioral problems being particularly important when caring for demented care 
recipients. This finding is supported by Black and Almeida's (2004) review of associations between behavioral and psychological symptoms of dementia and the burden on caregivers. They find a strong link with caregiver burden but, based on the weak correlation with depression, suggest that the concept of burden might be too broad to identify clinically relevant caregiving outcomes.

Another review by Cooper et al. (2007), in contrast, finds that dementia care is associated with higher levels of caregiver anxiety. An overview by Savage and Bailey (2004) likewise examines the impact of caring on caregivers' mental health but clusters relevant papers according to different factors associated with caregiver burden. They find that the care relationship is an important factor for mental health outcomes, with closer relationships inducing more positive outcomes for the caregiver. They also find evidence that mental impairment among care recipients negatively affects caregivers' well-being, an effect enhanced by financial restrictions and lack of social support. The importance of such social support is emphasized by both Lim and Zebrack (2004), who discuss its relation to stress, and Chappell and Reid (2002), whose path analysis confirms that caregiver burden is a predictor for caregiver well-being and mediator of caregiving characteristics. The amount of care provision that is informal increases the probability of feeling burdened and directly decreases wellbeing. Perceived social support and coping strategies reduce these downturns and increase caregiver well-being.

A small stream of literature even finds that being a caregiver can have positive impacts. For example, Cohen et al. (2002) observe that $73 \%$ of their Canadian sample could name at least one positive aspect of caregiving, including companionship, fulfilment, and enjoyment. Experiencing such care outcomes, however, was negatively related to depression, burden, and self-assessed health. Qualitative interviews by Ashworth and Baker (2000) also reveal direct positive effects: about $40 \%$ of the caregivers expressed satisfaction with care provision (see also Raschick \& Ingersoll-Dayton 2004). 
Positive outcomes are, however, rare or at least dominated by negative effects. Yet it should be noted that negative impacts can suffer from an upward bias generated by failure to control for the so-called family effect (Bobinac et al. 2010): the influence of having a family member with bad health. This effect is one that many studies fail to consider, which raises the risk of bias in simple comparisons between caregivers and noncaregivers. To avoid such bias, studies should carefully distinguish between the family effect and the caregiving effect. Amirkhanyan and Wolf (2006), for instance, find that care provision in the household affects the well-being of the entire family and simply having a parent in need of care increases the likelihood of depression. Likewise, Bobinac et al. (2010), after proxying the caregiver effect by the number of care tasks and the family effect by the actual health of the care recipient, show that both factors affect the caregiver's well-being by a comparable magnitude. They also provide evidence that not accounting for the family effect leads to a $30 \%$ overestimation of the caregiving effect. One additional methodological shortcoming noted by Leigh (2010) is that most of the caregiving research fails to account for omitted variable bias by ignoring important individual characteristics. In his study, the negative effect on life satisfaction becomes insignificant when individual fixed-effects are taken into account. Lawton et al. (2000) also find very little evidence that becoming a caregiver or caring over a long period worsens the caregiver's well-being.

The long-term impact of providing care to an ill or disabled parent (or parent-in-law) is a major focus of a study by Bookwala (2009), which draws on three waves of data collected over a 15-year period. Her research demonstrates that caregivers tend to suffer more over time, with well-being decreasing in the long term, which supports the so-called "wear-andtear” concept when caregivers do not adapt to their role. ${ }^{15}$ Hirst (2005), in contrast, finds that particularly intense caregiving - that is, providing more than 20 hours of care a week-is

\footnotetext{
15 “Wear-and-tear” refers to an increasing psychological burden over time, while "adaption” assumes a coping ability that reduces the burden in the long run (Brickman \& Campbell 1971).
} 
associated with the highest levels of distress when caregiving begins and after the caregiving spell has ended.

Bookwala (2009) also reveals that women experience a higher probability of depression after a certain time of caring, whereas men's depression levels decrease over the same amount of time. Female caregivers also generally report higher levels of depression, anxiety, and lower levels of well-being (Yee \& Schulz 2000), and the literature reviewed suggests almost exclusively stronger adverse effects for women than for men. Additional gender differences identified by Raschick and Ingersoll-Dayton (2004) using cross-sectional data include a tendency for women to be more burdened by the caregiving experience than men, to perceive more caregiving costs, and have lower levels of life satisfaction. Pinquart and Sörensen (2006), however, suggest that large gender differences can be partly explained by the fact that women tend to provide longer and more intense care. After accounting for the objective care burden in their meta-analysis of 229 studies, the remaining gender differences were small.

Raschick and Ingersoll-Dayton (2004) find that adult children receive higher emotional rewards than spouses, possibly because of qualitative differences in the care situation; that is, spouses face more intensive responsibilities than do adult children. These observations are echoed by Pinquart and Sörensen (2003a), who find that spouses who provide care are often more burdened than adult children who act as caregivers, possibly because spousal caregivers, being older, find the physical effort more onerous.

\section{Physical Health}

Studies on caregiving's impact on physical health are less widespread and have received less attention than studies on caregivers' psychological health. This literature does show, however, that physical health outcomes can be linked to informal caregiving through the following dynamics: (i) caregiving often requires physically demanding work over a long 
duration, which might cause musculoskeletal injuries and aggravation of arthritis and other chronic illnesses; (ii) caregivers tend to neglect a healthy lifestyle (e.g., diet and exercise); and (iii) caregiving increases stress and lowers psychological health, which is likely to manifest in such physical outcomes as hypertension and cardiovascular disease (Pinquart \& Sörensen 2007).

A meta-study by Vitaliano et al. (2003), which explores caregiving’s impact on physical health in 23 samples, does indicate that caregivers have worse physical health than noncaregivers; however, their assessment of different health categories shows significant but moderate differences in self-reported health, medication use, antibodies, and stress hormones. Another meta-analysis of the informal care literature, by Pinquart and Sörensen (2007), focuses exclusively on articles on physical health written between 1986 and the spring of 2006. In particular, this review concentrates on the following care-affiliated factors that specifically impact caregivers’ physical health: (i) mentally impaired care recipients and behavioral problems; (ii) characteristics of the care situation, such as care duration, coresidency, nonspousal care, and lower levels of informal care support; (iii) the caregiver characteristics of high age and lower socioeconomic status; and (iv) a high caregiving burden and symptoms of caregiver depression. Based on their review, the authors conclude that physical health losses among caregivers are more likely to be related to their mental health status than to physical overload. They base this conclusion on the lack of a significant correlation between a care recipient's physical impairment and the caregiver's physical health status. At the same time, however, they also find a high correlation between a care recipient's mental illness or a caregiver's depression and physical health (see also, Schulz et al. 1995). As Pinquart and Sörensen (2007) point out, the most severe physical impairments can be found among caregivers who are older, male, or in charge of dementia patients, a risk group slightly different from those identified in the psychological health research, in which women in particular perceive a higher cost of caring (Raschick \& Ingersoll-Dayton 2004). 
The general association between informal care and worse health is demonstrated by Legg et al. (2013), who employ UK census data to reveal a significant negative association between care and health that becomes stronger with care hours provided (see also Ugreninov 2013). Likewise, Mentzakis et al. (2009), using 14 waves of the British Household Panel (BHPS) to explore the determinants of caregiving, identify a significant correlation between worse health and the probability that the caregiver is providing residential care.

Dementia caregiving, in particular, is associated with a high burden and overall downturns in health, as demonstrated by Schoenmakers et al.’s (2010) meta-analysis of its impact, which supports most of Pinquart and Sörensen’s (2007) observations. Nevertheless, although both reviews conclude that dementia caregiving is associated with lower physical health, they both admit to the following caveats: (i) the literature reviewed is very heterogeneous and therefore minimally comparable, (ii) most studies are cross-sectional and thus do not account for endogeneity, and (iii) research often omits important controls (e.g., preexisting illness).

One particularly strong predictor of an individual's own health is spousal health, which emerges prominently in all self-reported surveys, even in households where no care is needed (Satariano et al. 1984). At the same time, however, research results based on more objective measures like doctor visits and drug use remain ambiguous. In addition, although stressful caregiving may not overtly affect actual health status during the period of caring, it can be related to subsequent downturns in immune function. Such a lagged effect of caregiving is demonstrated by the sample of single mothers providing intergenerational care in which physical downturns like lower self-assessed health and high blood pressure occurred after a 2to 4-year delay (Coe \& Van Houtven 2009). Similarly, in a study by Gräsel (2002), although caregivers experienced no health decrease over the caregiving period, after leaving the caregiver role, they experienced uplifts in health but nearly twice as many doctor visits, which the author interprets as a strengthened awareness of their own health, neglected while a caregiver. 
In contrast to these mostly negative associations, other studies draw a more ambivalent picture. For example, Vlachantoni et al. (2012), in their review of caregiving's impact on health measures in Britain, underscore the ambiguous results on caregiver characteristics. In an analysis of the differences between cross-sectional and longitudinal studies, they also find that, depending on the sample and model used, cross-sectional analyses may find positive, negative, or no correlation. In particular, they highlight a study by O’Reilly et al. (2008), based on a sample from the Northern Ireland Census, which shows that caregiving is related both to poorer health and lower levels of physical impairment and mortality. Although this link between caregiving and lower mortality is supported elsewhere (Brown et al. 2003), Schulz and Beach (1999) demonstrate that mortality rates are higher among caregivers who report emotional strain than among noncaregivers. On the other hand, caregivers who do not report a high burden from their tasks seem to have the same mortality risk as the comparison group. O’Reilly et al. (2008) therefore conclude that previous literature underestimates the positive health outcomes associated with caregiving.

One possible explanation for this ambiguous outcome is that caregiving can induce a psychological uplift that may increase physical health by enhancing well-being (Ashworth \& Baker 2000). Another explanation may be self-selection out of the caregiver role when the severity of the physical impairment makes care impossible. In such cases, public support could provide different options for selecting out of the caregiver role when the adverse health effects become too severe or at least reduce the care intensity. Empirical evidence for this notion is provided by Dujardin et al. (2011), who show in a country comparison that a heavy care burden, although more prevalent in Britain than in Belgium, has a less adverse health effect for British caregivers, probably because of the better public support. If researchers are to avoid biased results, therefore, they must additionally account for self-selection into caring. For example, although it seems rational to assume that when caregivers have free choice, only those with robust health are likely to become caregivers, Coe and Van Houtven (2009) find 
decreased self-rated health measures for both male and female care providers even after they account for self-selection.

\section{Family Implications}

Caregiving competes with leisure time, which is usually spent with family members and helps maintain healthy family relationships. The time for leisure, however, is drastically shortened when caregiving lasts for hours or must be combined with a regular workday. Caring for co-residing elderly, in particular, not only influences a family's daily life but decreases the well-being of both caregivers and their family members (Amirkhanyan \& Wolf 2006). Yet the effect of caregiving on the entire family has received only marginal attention in the research. The few studies that do exist (see table 3) focus especially on informal caregiving's effect on married couples. For example, Bookwala (2009) ${ }^{16}$ finds that among a sample of adult caregiving daughters and sons, experienced caregivers are significantly less happy in their marriages than those who have just assumed the caregiving role. ${ }^{17}$ Likewise, former caregivers experience greater differences than recent caregivers, long-term caregivers experience more than noncaregivers, and, in terms of gender inequality, these effects are stronger for females in both groups. These findings are consistent with the already cited research showing that it takes time for the impacts of caregiving to manifest in any measurable magnitude and that downturns in overall life satisfaction come to include downturns in satisfaction with family life.

On the other hand, Litvin et al. (1995) argue that if care provision is exogenous, then the double burden perceived by married caregivers can be counterbalanced by spousal support in the caregiving process. In fact, Brody et al. (1995) do find that well-being among married caregivers is highest, while never-married caregivers are less likely to co-reside with parents than their married counterparts. Moreover, although married daughters do not differ

\footnotetext{
${ }^{16}$ For details, see table 2 .

17 Bookwala (2009) observed three caregiver groups in three waves: T1 (1987-1988), T2 (1992-1994), and T3 (2001-2002). Caregivers in T1 were subjected to a baseline interview, "experienced caregivers" provided care in T2 and T3, but only "former caregivers" provided care in T2 and only "recent caregivers" in T3.
} 
significantly from separated and divorced female caregivers in terms of co-residency, there are directional differences: whereas most of the latter have moved back into their parents' home, the majority of married caregivers co-reside in their own dwelling. This pattern appears to be driven by the opportunity to provide better care, on the one hand, and by financial problems, on the other, particularly in the case of divorced daughters. In fact, Young and Grundy (2008), using data for England and Wales, find that the share of caregivers is higher among the never married than among married or formerly married men and women.

In an attempt to describe the decision-making process within the family, Pezzin and Schone (1999) develop a theoretical model in which parents and their children (in this case, only daughters) both agree to a Nash bargaining rule by which the household formation itself is endogenous. Both parents and daughters want to maximize their utility dependent on altruism, informal care, formal care, and leisure time and will only co-reside if both parties derive positive utility from this solution. Maximal family consumption depends on satisfaction of the parents' care needs by allowing the daughter to (i) provide informal care herself and trade off leisure or (ii) increase financial transfers for a formal care solution. Substitution between the two choices depends on the daughter's wage, with higher opportunity costs for care leading to a lower probability of providing informal care and therefore shared residency. The authors test their theoretical approach using a complete data set of 424 parent-daughter pairs from Israel. Their estimates show significantly negative coefficients for married daughter, daughter's age, and number of daughter's children. For married parents, the likelihood of co-residency is small but increases significantly with degree of parent impairment.

\section{Conclusions}

As an aging population increases the demand for caregiving, societies are being forced to develop strategies for providing a sufficient supply of care, a large share of which is informal. 
Hence, to formulate successful policies, policy-makers must be aware not only of the social implications of informal care's effects on the caregiver but of the economic consequences of changes within the care arrangements. Yet although the implications for the job market have become of major interest to researchers in recent years, the findings on informal caregiving's overall effect remain ambiguous. Whereas most studies report a negative link between care and employment, some relate a reduction in employment or work hours only to specific characteristics, with female co-residing caregivers being the most affected. The magnitude of these effects, however, appears rather small: caregivers seem to have a lower attachment to the labor force even before they enter the caregiver role. Likewise, the probability of informal caregivers being employed is at most $5-10 \%$ lower than that for noncaregivers. Stronger effects could be obtained for very intense caregiving, which is provided primarily by females of working age, who are less likely to be fully employed and earn generally lower wages. Only high family income and strong social support enables families to freely choose an arrangement that is satisfying to all family members, so willingness to care remains a result of circumstances. Even with full employment, low wealth and no alternatives within the family increase the pressure to provide care (Carmichael et al. 2008).

For psychological health measures, the results are more homogeneous: the majority of studies find a negative impact of caregiving on mental health. That is, even though caregiving can create psychological uplifts, the negative consequences tend to dominate, particularly for female and spousal caregivers. Such negative outcomes not only affect the caregiver per se but also the caregiver's family. As regards physical health, there is less conclusive evidence for specific risk groups within the literature: the general negative association of caregiving and physical health outcomes is often related to psychological downturns.

The link between marital status and caregiving is twofold: first, married caregivers seem to cope best with the caregiving burden, possibly because of more social support and a better financial situation. Second, the generally accepted reality that too much stress can harm a 
relationship also holds for caregiving, in which a longer duration of care negatively affects marital satisfaction. Nevertheless, the empirical findings are sparse, so further research is needed.

It should also be noted that the three categories analyzed in this paper (employment, health, and family) mutually affect each other. For example, occupation and marital status both affect health levels while poor health is linked to both unemployment and working overtime (Bell et al. 2012, Brown et al. 2012), but being married is associated with higher levels of both income (Antonovics \& Town 2004) and health (Helmert \& Shea 1998). As important, these effects are not only cumulative but may spill over into other domains and reinforce each other. For instance, combining full-time work and care can be related to lower health (Farfan-Potret et al. 2009) or a higher usage of antidepressants (Schmitz \& Stroka 2013). Likewise, downturns in psychological health generated by the caregiving burden could affect work performance and thus increase the risk of unemployment, which is itself a psychological stressor. Obviously, these linkages are complex and require sophisticated analysis if the different effects are to be isolated.

The majority of existing studies, however, are subject to methodological shortcomings, including nonrepresentative or small samples, limited use of control variables (Bobinac et al. 2010), and widespread use of cross-sectional analyses (Schulz et al. 1990). In particular, because decisions to provide care can be endogenous with the outcomes of interest (Coe \& Van Houtven 2009), not accounting for selection in and out of the caregiver role or simultaneous decision-making biases empirical findings. Nevertheless, with regard to employment, recent studies raise doubts about the endogeneity of its relationship with care (e.g., Bolin et al. 2008b, Ciani 2012, Meng 2012, Van Houtven et al. 2013, Nguyen \& Connelly 2014) or criticize the approach being used (Hassink \& Van den Berg 2009). Nor should analyses be restricted to the individual caregiver: if studies are to obtain conclusive evidence on the effects of caregiving, they must also incorporate caregivers' families and 
formally supported alternatives (Amirkhanyan \& Wolf 2006).

Today, such alternatives to informal care are finding an increasing market and are, to some extent, available in all developed countries. With the right public policies, therefore, formal support can relieve caregivers (Bolin et al. 2008a) and help care receivers avoid hospitalization (Bonsang 2009, Jiménez-Martín \& Prieto 2012). However, because caregiving arrangements are heterogeneous, flexible public support is needed that is adaptable to caregiver needs. Based on our analysis, we draw two conclusions related to achieving this goal: first, even though the individual outcomes on employment and health seem rather small, the literature suggests that the effects of caregiving are mostly negative. Such negative outcomes must therefore be considered part of the cost of informal care when defining the opportunity costs of formal care subsidies. Second, most studies reviewed find that the caregiver burden is higher for women than for men. One contributory factor may be that traditional gender roles place greater pressure on women to commit to the caregiver role, even though they face relatively higher caregiving costs, different expectations that contribute to the existing gender wage gap. As demand rises, it seems likely that, despite increasing female labor force participation and the softening of traditional gender roles, women will be more at risk of having to deal with a family member in need of care. 
Table 1 Studies on Informal Care and Employment

\begin{tabular}{|c|c|c|c|}
\hline Author & Data & Controls & Key results \\
\hline \multicolumn{4}{|c|}{ Literature review or meta study } \\
\hline Lilly et al. (2007) & Review of 34 articles (1986-2006) & - & $\begin{array}{l}\text { Carers generally do not show lower levels of } \\
\text { employment, but intense caregiving is related } \\
\text { to lower working hours and lower levels of } \\
\text { labor force participation }\end{array}$ \\
\hline \multicolumn{4}{|c|}{ Studies accounting for or ruling out endogeneity and/or account for unobserved heterogeneity } \\
\hline Berecki-Gisolf et al. (2008) & $\begin{array}{l}\text { N=9,837, Australian Longitudinal Study on } \\
\text { Women's Health }(2001 \& \text { 2004, L) }\end{array}$ & $\begin{array}{l}\text { Selection in care, health of care receiver, } \\
\text { caregiver demographics }\end{array}$ & $\begin{array}{l}\text { Employment does not affect selection into } \\
\text { caregiver role, but providing care is related to } \\
\text { odds ratios up to } 2.11 \text { for reducing work hours } \\
\text { or leaving employment }\end{array}$ \\
\hline Bolin et al. (2008b) & $\begin{array}{l}N=3,769 \text {. Survey of Health, Ageing and } \\
\text { Retirement in Europe }(2004, C)\end{array}$ & $\begin{array}{l}\text { OLS, 2SLS, regional differences, caregiver } \\
\text { demographics }\end{array}$ & $\begin{array}{l}\text { Exogeneity of caregiving could not be } \\
\text { rejected. Evidence for reduced employment } \\
\text { probability, and working hours. Results vary } \\
\text { between north and south Europe }\end{array}$ \\
\hline Carmichael et al. (2010) & $\begin{array}{l}\mathrm{N}=20,000 \text {, British Household Panel Survey } \\
(1991-2005, \mathrm{~L})\end{array}$ & $\begin{array}{l}\text { Previous care provision, caregiver demo- } \\
\text { graphics, co-residential care }\end{array}$ & $\begin{array}{l}\text { Occupation and earnings negatively affect the } \\
\text { probability of demanding care provision }\end{array}$ \\
\hline Casado-Marin et al. (2011) & $\begin{array}{l}\text { Spanish female subsample of the European } \\
\text { Community Household Panel (1994-2001, L) } \\
\text { between } 30-60 . \mathrm{N}=28,260 \text {. }\end{array}$ & $\begin{array}{l}\text { Ordered probit, IPW estimator against } \\
\text { attrition, caregiver characteristics }\end{array}$ & $\begin{array}{l}\text { Lower probabilities for employment were } \\
\text { observed for women caring for someone at } \\
\text { home and for those who care for more than } \\
\text { one period }\end{array}$ \\
\hline Ciani (2012) & $\begin{array}{l}\text { European Community Household Panel } \\
\text { (1994-2001, L) with women between 40-59 } \\
\text { and men 40-64 with about 300,000 } \\
\text { observations }\end{array}$ & $\begin{array}{l}\text { Endogeneity and individual effects, caregiver, } \\
\text { and care receiver characteristics }\end{array}$ & $\begin{array}{l}\text { Once individual fixed-effects are accounted } \\
\text { for, the exogeneity assumption for informal } \\
\text { care could not be rejected. Effects are small } \\
\text { and differ between north and south Europe }\end{array}$ \\
\hline Heitmueller (2007) & $\begin{array}{l}\text { N=25,000, British Household Panel Survey } \\
\text { (1991-2003, C \& L) }\end{array}$ & $\begin{array}{l}\text { Endogeneity, co- and extra-resident care, } \\
\text { intensity, caregiver demographics }\end{array}$ & $\begin{array}{l}\text { Endogeneity is important if the impact of care } \\
\text { on employment decisions is not to be } \\
\text { overestimated. Negative linkage is observed } \\
\text { for co-residential and intensive care only }\end{array}$ \\
\hline Heitmueller \& Inglis (2007) & $\begin{array}{l}\text { British Household Panel Survey (1993 \& } \\
\text { 2002), about 5,000 observations }\end{array}$ & $\begin{array}{l}\text { Heckmen procedure for selection, caregivers } \\
\text { characteristics }\end{array}$ & $\begin{array}{l}\text { Employed carers are expected to earn about } \\
6 \% \text { less than non-carers. The wage penalty is } \\
\text { estimated to be } 1.04 \text { pounds/hour }\end{array}$ \\
\hline Johnson \& Lo Sasso (2006) & $\begin{array}{l}\text { Household and Retirement Survey (1996- } \\
\text { 1998, L) about 2,500 women between 55-67 }\end{array}$ & $\begin{array}{l}\text { Instrumental variables, family and caregiver } \\
\text { characteristics }\end{array}$ & $\begin{array}{l}\text { Caregiving substantially reduces working } \\
\text { hours; not accounting for individual } \\
\text { heterogeneity might underestimate the effect }\end{array}$ \\
\hline King \& Pickard (2013) & $\begin{array}{l}\mathrm{N}=17,123 \text {. English Longitudinal Study of } \\
\text { Ageing (2002-2009, L) aged 50-64. }\end{array}$ & Logit, caregiver characteristics & $\begin{array}{l}\text { Those providing more than } 10 \text { hours of care } \\
\text { show lower levels of employment }\end{array}$ \\
\hline Kotsadam (2011) & $\begin{array}{l}\mathrm{N}=14,478 \text {, European Community Household } \\
\text { Panel (1994-2001, L), females from } 14 \\
\text { countries. }\end{array}$ & $\begin{array}{l}\text { Random-/fixed-effects logit, probit, caregiver } \\
\text { characteristics }\end{array}$ & $\begin{array}{l}\text { Effects on working hours and employment } \\
\text { probability vary within Europe and are larger } \\
\text { in southern countries }\end{array}$ \\
\hline Leigh (2010) & 7 waves of HILDA $(2001-2007, \mathrm{~L})$ with & Pooled OLS and fixed-effects model & After accounting for individual \\
\hline
\end{tabular}




\begin{tabular}{|c|c|c|c|}
\hline Author & Data & Controls & Key results \\
\hline & 8,000 to 10,000 observations & & $\begin{array}{l}\text { characteristics, only small effects emerged for } \\
\text { care and employment, while subjective well- } \\
\text { being remained unaffected }\end{array}$ \\
\hline Meng (2012) & $\begin{array}{l}\text { N=14,873, German Socio-Economic Panel } \\
(2001-2007)\end{array}$ & $\begin{array}{l}\text { Endogenity, fixed-effects, caregiver and care } \\
\text { receiver characteristics }\end{array}$ & $\begin{array}{l}\text { Labor force participation is not significantly } \\
\text { reduced. Providing } 10 \text { hours more of care a } \\
\text { week reduces working hours by less than } 50 \\
\text { minutes }\end{array}$ \\
\hline Michaud et al. (2010) & $\begin{array}{l}\text { Females age } 25 \text { to } 59 \text { from the British } \\
\text { Household Panel Study }(2000-2005, \mathrm{~L}) \\
\mathrm{N}=2,551\end{array}$ & $\begin{array}{l}\text { Co- and extra-resident care, endogeneity of } \\
\text { care provision, partner, and partner’s family, } \\
\text { caregiver demographics }\end{array}$ & $\begin{array}{l}\text { Small but significant effect of co-residential } \\
\text { caregiving on future employment }\end{array}$ \\
\hline Moscarola (2010) & $\begin{array}{l}\mathrm{N}=9,656 \text {, Dutch women } 25-55 \text { from the } \\
\text { European Community Household Panel } \\
\text { Surveys (1995-2001, L) }\end{array}$ & $\begin{array}{l}\text { Dynamic bivariate probit for simultaneous } \\
\text { estimation with lagged care and work } \\
\text { variables, caregiver characteristics }\end{array}$ & $\begin{array}{l}\text { Employees are less likely (5.8\%) to become } \\
\text { caregivers and vice versa (2.4\%). }\end{array}$ \\
\hline Nguyen \& Connelly (2014) & $\begin{array}{l}8 \text { waves of HILDA (2001-2008) with 7,845 } \\
\text { observations between } 25-64\end{array}$ & $\begin{array}{l}\text { Instrumental variable, multinomial logit, } \\
\text { endogeneity, co- and extra-resident care, care } \\
\text { intensity, caregiver demographics }\end{array}$ & $\begin{array}{l}\text { Endogeneity of the caregiving decision was } \\
\text { rejected and therefore the estimates were } \\
\text { treated exogenous. Results suggest that } \\
\text { caregiving reduces labor force participation } \\
\text { by around } 12 \% \text { for men and women }\end{array}$ \\
\hline Van Houtven et al. (2013) & $\begin{array}{l}\text { Health and Retirement Study (1992-2008, L) } \\
\text { with around 4,000 men and women. }\end{array}$ & $\begin{array}{l}\text { Instrumental variable, fixed-effects, care } \\
\text { tasks, caregiver characteristics. }\end{array}$ & $\begin{array}{l}\text { Endogeneity was only found for the work } \\
\text { hours equations and drastically increased the } \\
\text { negative association. Exogenous estimates for } \\
\text { employment probability and wages remained } \\
\text { mostly not significant. Women were more } \\
\text { likely to retire }\end{array}$ \\
\hline Viitanen (2010) & $\begin{array}{l}\text { European Community Household Panel } \\
(1994-2001, \mathrm{~L}) \text { around 900,000 observations } \\
\text { from } 13 \text { countries. }\end{array}$ & $\begin{array}{l}\text { Unobserved heterogeneity, caregiver } \\
\text { characteristics }\end{array}$ & $\begin{array}{l}\text { Only in Germany do women providing care } \\
\text { show a significant lower labor force } \\
\text { participation }\end{array}$ \\
\hline \multicolumn{4}{|c|}{ Other studies } \\
\hline Bittman et al. (2007) & $\begin{array}{l}4 \text { waves of the Household Income and Labour } \\
\text { Dynamics in Australia with up to 7,500 } \\
\text { observations }\end{array}$ & $\begin{array}{l}\text { OLS, probit, caregiver characteristics, } \\
\text { descriptive comparison }\end{array}$ & $\begin{array}{l}\text { Caregivers show lower earnings and working } \\
\text { hours, and starting caregiving is related to a } \\
\text { higher probability of leaving the labor force }\end{array}$ \\
\hline Carmichael \& Charles (2003) & $\begin{array}{l}\mathrm{N}=10,000 \text {, General Household Survey } \\
(1990, \mathrm{C})\end{array}$ & $\begin{array}{l}\text { Co- and extra-resident care, caregiver demo- } \\
\text { graphics }\end{array}$ & $\begin{array}{l}\text { Men }(-12.9 \%) \text { suffer less than women }(-27 \%) \\
\text { in terms of employment probability. } \\
\text { However, both face lower wages }\end{array}$ \\
\hline Carmichael et al. (2008) & $\begin{array}{l}\text { N=272 respondents recruited among support } \\
\text { groups \& British Household Panel Survey } \\
(1991-2001, \text { C) }\end{array}$ & $\begin{array}{l}\text { Hours and years of caregiving, caregiver } \\
\text { demographics }\end{array}$ & $\begin{array}{l}\text { Longer hours and longer duration of care } \\
\text { increase the likelihood of changing work } \\
\text { hours or leaving employment completely }\end{array}$ \\
\hline Dautzenberg et al. (2000) & $\mathrm{N}=581$, Telephone survey (1994 \& 1996, L) & $\begin{array}{l}\text { Distance to and health of care recipient, } \\
\text { siblings, and caregiver demographics }\end{array}$ & $\begin{array}{l}\text { Unemployed daughters and daughters living } \\
\text { nearby are more likely to become caregivers. } \\
\text { Care and work hours are unrelated }\end{array}$ \\
\hline Gautun \& Hagen (2010) & Survey with 4,000 Norwegians between 45-65 & Descriptive univariate analysis & $75 \%$ of caregivers experience problems \\
\hline
\end{tabular}




\begin{tabular}{|c|c|c|c|}
\hline Author & Data & Controls & Key results \\
\hline & $(2006, C)$ & & $\begin{array}{l}\text { combining work and caregiving, mostly in } \\
\text { terms of irregular work hours and lack of } \\
\text { participation in training and meetings }\end{array}$ \\
\hline Lee \& Tang (2013) & $\begin{array}{l}N=5,119 \text {, Health and Retirement Study } \\
(2004, C)\end{array}$ & $\begin{array}{l}\text { Spousal, parental, and grandchild care, demo- } \\
\text { graphics }\end{array}$ & $\begin{array}{l}\text { Parental personal care was associated with a } \\
\text { significantly lower odds ratio }(0.49) \text { for } \\
\text { women. No effect emerged for men }\end{array}$ \\
\hline Lilly et al. (2010) & $\begin{array}{l}\text { Statistics Canada's 2002, C, General Social } \\
\text { Survey with } 24,855 \text { observations above } 45\end{array}$ & $\begin{array}{l}\text { Probit, two-stage Heckman procedure to } \\
\text { account for selection in the wage/work hours } \\
\text { regression, caregiver demographics }\end{array}$ & $\begin{array}{l}\text { The results suggest that it is mostly primary } \\
\text { caregivers that show lower levels of labor } \\
\text { force participation. Employed caregivers } \\
\text { show neither lower working hours nor lower } \\
\text { wages. Secondary caregivers seem unaffected }\end{array}$ \\
\hline Pavalko \& Henderson (2006) & $\begin{array}{l}\mathrm{N}=2,021 \text {, National Longitudinal Survey of } \\
\text { Young Women }(1995-2001, \mathrm{~L})\end{array}$ & $\begin{array}{l}\text { Logit, caregiver characteristics, firm } \\
\text { characteristics, work place benefits }\end{array}$ & $\begin{array}{l}\text { Caregiving women with more flexible } \\
\text { working contracts were more likely to remain } \\
\text { in the labor force }\end{array}$ \\
\hline Reid et al. (2010) & $\begin{array}{l}\text { N=136, Employed caregivers from Victoria, } \\
\text { British Columbia (1999-2000, C) }\end{array}$ & - & $\begin{array}{l}\text { Caregiving might interfere with work in terms } \\
\text { of quality, which is not measured through } \\
\text { employment status or work hours }\end{array}$ \\
\hline Spiess \& Schneider (2003) & $\begin{array}{l}\text { N=6,400 women aged } 45 \text { to 59, European } \\
\text { Community Household Panel Surveys (1994 } \\
\text { \&1996, L) }\end{array}$ & $\begin{array}{l}\text { Cross-national comparison, focus on changes } \\
\text { to control for selection, caregiver } \\
\text { demographics }\end{array}$ & $\begin{array}{l}\text { Starting and increasing care lowers working } \\
\text { hours, not vice versa. Results differ along a } \\
\text { north-south gradient within Europe }\end{array}$ \\
\hline Ugreninov (2013) & $\begin{array}{l}\mathrm{N}=3,969 \text { full-time worker from the } \\
\text { Norwegian study of life course, ageing, and } \\
\text { generation }(2008, \mathrm{C})\end{array}$ & $\begin{array}{l}\text { Probit, caregiver characteristics, work-place } \\
\text { characteristics. }\end{array}$ & $\begin{array}{l}\text { Full-time caregivers have more absences for } \\
\text { sickness and lower health than noncaregivers. }\end{array}$ \\
\hline Wakabayashi \& Donato (2005) & $\begin{array}{l}\mathrm{N}=2,638 \text {, Female subsample form the Na- } \\
\text { tional Survey of Family and Household } \\
(1987 / 88 \text { \& 1992-1994, L) }\end{array}$ & $\begin{array}{l}\text { Enter, remain, and quit caregiver role. Social } \\
\text { demographics }\end{array}$ & $\begin{array}{l}\text { Substantial reduction in employment, work } \\
\text { time, and earnings when becoming a } \\
\text { caregiver. Ceasing to give care is not } \\
\text { associated with any counteracting effect. }\end{array}$ \\
\hline
\end{tabular}

2SLS= two-stage least squares, $\mathrm{C}$ = cross-section, $\mathrm{L}$ = longitudinal, 
Table 2 Studies on Informal Care and Health

\begin{tabular}{|c|c|c|c|}
\hline Author & Data & Controls & Key results \\
\hline \multicolumn{4}{|c|}{ Literature review or meta study } \\
\hline Black \& Almeida (2004) & $\begin{array}{l}\text { Review of } 30 \text { cross-sectional (meta-analysis) } \\
\text { and } 12 \text { longitudinal (1990-2001) }\end{array}$ & - & $\begin{array}{l}\text { Behavioral and psychological symptoms of } \\
\text { dementia correlate with caregiver burden, but } \\
\text { only to a small degree with depression }\end{array}$ \\
\hline Cooper et al. (2007) & Review of 32 studies (1988-2005) & - & $\begin{array}{l}\text { One fourth of dementia caregivers reported } \\
\text { clinically significant anxiety levels, higher } \\
\text { than the noncaregiver controls. Coping, } \\
\text { perceived burden, and physical health were } \\
\text { the only clear associations found }\end{array}$ \\
\hline Etters et al. (2008) & Review of literature (1996-2006) & - & $\begin{array}{l}\text { The dementia caregiving burden leads to } \\
\text { deterioration of caregiver health, which can } \\
\text { result in early nursing home placement }\end{array}$ \\
\hline Lim \& Zebrack (2004) & Review of 19 studies (1987-2004) & - & $\begin{array}{l}\text { Care receiver and caregiver characteristics, } \\
\text { coping methods, and social support are } \\
\text { predictors for caregiver quality of life } \\
\text { measures }\end{array}$ \\
\hline Pinquart \& Sörensen (2003a) & Review of 228 studies(1966-2002) & - & $\begin{array}{l}\text { Behavioral problems, physical and cognitive } \\
\text { impairment, and care time increase } \\
\text { depression, and spouses who provide care are } \\
\text { often more burdened than adult children }\end{array}$ \\
\hline Pinquart \& Sörensen (2003b) & Review of 84 studies(1987-2002) & - & $\begin{array}{l}\text { A comparison of caregivers with } \\
\text { noncaregivers shows significantly lower } \\
\text { mental health but only small differences in } \\
\text { physical health. Dementia caregiving had } \\
\text { stronger effects }\end{array}$ \\
\hline Pinquart \& Sörensen (2006) & Meta-analysis of 229 studies (1983- 2005) & - & $\begin{array}{l}\text { Differences between female and male carers } \\
\text { were small. Women perceived greater adverse } \\
\text { effects of care with regards to burden, } \\
\text { depression, well-being, and physical health }\end{array}$ \\
\hline Pinquart \& Sörensen (2007) & Review of 176 articles (1982-2006) & - & $\begin{array}{l}\text { Reasons for physical downturns can be found } \\
\text { in psychological associations with care. Being } \\
\text { older, male, or a dementia caregivers } \\
\text { increases the risk for physical health problems }\end{array}$ \\
\hline Savage \& Bailey (2004) & Review of 26 studies (1979-2002) & - & $\begin{array}{l}\text { Care recipient disabilities and residency } \\
\text { influence the impact of caring on the } \\
\text { caregiver. }\end{array}$ \\
\hline Schoenmakers et al. (2010) & $\begin{array}{l}\text { Review of } 207 \text { articles on dementia caregiver } \\
(1990-2009)\end{array}$ & - & $\begin{array}{l}\text { Caregiver characteristics are more important } \\
\text { for the observed negative impact on health } \\
\text { than for objective care needs. }\end{array}$ \\
\hline Schulz et al. (1990) & Review of 33 articles (1978-1990) & - & Caregivers tend to have higher levels of \\
\hline
\end{tabular}




\begin{tabular}{|c|c|c|c|}
\hline Author & Data & Controls & Key results \\
\hline & & & $\begin{array}{l}\text { psychiatric symptoms than the average } \\
\text { population }\end{array}$ \\
\hline Schulz et al. (1995) & Review of 41 articles (1989-1995) & - & $\begin{array}{l}\text { Substantial evidence in the literature that } \\
\text { dementia caregiving leads to higher levels of } \\
\text { depression }\end{array}$ \\
\hline Vlachantoni et al. (2012) & Review of 20 studies (1992-2012) & - & $\begin{array}{l}\text { Caregiver characteristics are important; lon- } \\
\text { gitudinal designs tend to show less severe ef- } \\
\text { fects on health outcomes }\end{array}$ \\
\hline Vitaliano et al. (2003) & $\begin{array}{l}\text { Meta-analysis of studies 45, based on } 23 \\
\text { samples of dementia caregivers (1987-1999) }\end{array}$ & - & $\begin{array}{l}\text { Small but significant correlation with several } \\
\text { health outcomes, including subjective self- } \\
\text { assessed health and objective measures (e.g., } \\
\text { biomarkers) }\end{array}$ \\
\hline Yee \& Schulz (2000) & Review of 30 reports (1985-1998) & - & $\begin{array}{l}\text { Caregivers report higher psychiatric morbidity } \\
\text { than noncaregivers. A gender comparison } \\
\text { shows women are more affected than men. }\end{array}$ \\
\hline \multicolumn{4}{|c|}{ Studies accounting for or ruling out endogeneity and/or account for unobserved heterogeneity } \\
\hline Amirkhanyan \& Wolf (2006) & $\begin{array}{l}\text { N=7,009, Health Retirement Study } \\
(1996,1998,2000, L)\end{array}$ & $\begin{array}{l}\text { Family relations, care recipient ADL, } \\
\text { caregiver demographics, random-effects }\end{array}$ & $\begin{array}{l}\text { Generally, noncaregivers whose parents need } \\
\text { money for transportation are more likely to } \\
\text { show symptoms of depression than caregivers } \\
\text { without disabled relatives. }\end{array}$ \\
\hline Coe \& Houtven (2009) & $\begin{array}{l}\mathrm{N}=3316 \text {, subsamples of the Health and Re- } \\
\text { tirement Survey (1992-2004, L) }\end{array}$ & $\begin{array}{l}\text { Dynamic model, instrumental variables, } \\
\text { random-and fixed-effects, family relationship, } \\
\text { caregiver demographics }\end{array}$ & $\begin{array}{l}\text { Negative impacts on physical health emerge } \\
\text { with a 2-year delay }\end{array}$ \\
\hline Mentzakis et al. (2009) & $\begin{array}{l}N=84,000 \text {, British Household Panel Survey } \\
(1991-2004, \text { L) }\end{array}$ & $\begin{array}{l}\text { Estimates supply of care, lagged care, } \\
\text { caregivers, household, and formal care } \\
\text { controls }\end{array}$ & $\begin{array}{l}\text { The extensive margin shows a negative } \\
\text { significant correlation between health and the } \\
\text { probability to provide care }\end{array}$ \\
\hline \multicolumn{4}{|c|}{ Other studies } \\
\hline Ashworth \& Baker (2000) & $\mathrm{N}=23$, Qualitative interviews with caregivers & - & $\begin{array}{l}\text { About } 40 \% \text { of caregivers report positive } \\
\text { outcomes of caregiving }\end{array}$ \\
\hline Bookwala (2009) & $\begin{array}{l}\text { N=716, National Survey of Families and } \\
\text { Households }(1987 / 88,1992 / 94,2001 / 02, L)\end{array}$ & $\begin{array}{l}\text { Selection into caregiving, caregiver } \\
\text { demographics }\end{array}$ & $\begin{array}{l}\text { In contrast to female caregivers, males show a } \\
\text { decline in depression symptoms over time. } \\
\text { Experienced caregivers are significantly less } \\
\text { happy in their marriages than recent } \\
\text { caregivers }\end{array}$ \\
\hline Chappell \& Reid (2002) & $\begin{array}{l}\text { N=243, telephone interviews in British } \\
\text { Columbia, Canada , C) }\end{array}$ & $\begin{array}{l}\text { SEM models, care recipient characteristics, } \\
\text { caregiver demographics }\end{array}$ & $\begin{array}{l}\text { Perceived social support }(+) \text {, self-esteem }(+) \text {, } \\
\text { informal care hours }(-) \text {, and burden }(-) \text { have a } \\
\text { significant influence on caregivers' mental } \\
\text { health }\end{array}$ \\
\hline Cohen et al. (2002) & $\begin{array}{l}\mathrm{N}=289 \text {, subsample from the Canadian Study } \\
\text { of Health and Aging }(1996, \mathrm{C})\end{array}$ & $\begin{array}{l}\text { Stepwise regression, caregiving relationship, } \\
\text { residency, care receiver, caregiver age, and } \\
\text { gender }\end{array}$ & $\begin{array}{l}73 \% \text { of caregivers perceive at least one } \\
\text { positive outcome of caregiving, which } \\
\text { positively affects mental and physical health }\end{array}$ \\
\hline Dujardin et al. (2011) & Census data from Britain $(\mathrm{N}=1,361,222)$ and & Logit, caregiver characteristics, regional & Caregiving is more prevalent in Britain than \\
\hline
\end{tabular}




\begin{tabular}{|c|c|c|c|}
\hline Author & Data & Controls & Key results \\
\hline & Belgium $(\mathrm{N}=4,368,637)$ & matching & $\begin{array}{l}\text { in Belgium, but British caregiver have better } \\
\text { health }\end{array}$ \\
\hline Gräsel (2002) & $\begin{array}{l}\mathrm{N}=681 \text {, caregivers, re-interviewed after } \\
12 \text { months }\end{array}$ & MANOVA & $\begin{array}{l}\text { Terminating the caregiver role is associated } \\
\text { with uplifts in health and frequency of doctor } \\
\text { visits }\end{array}$ \\
\hline Hirst (2005) & $\begin{array}{l}\text { N=25,000, British Household Panel Survey } \\
(1991-2000, \mathrm{~L})\end{array}$ & $\begin{array}{l}\text { Logit, care intensity, care duration, care } \\
\text { location, and relationship }\end{array}$ & $\begin{array}{l}\text { Starting or leaving intense caregiving is } \\
\text { associated with high psychological distress }\end{array}$ \\
\hline Lawton et al. (2000) & $\begin{array}{l}\text { N=634, Volunteer female sample (1990- } \\
1994, \mathrm{C})\end{array}$ & $\begin{array}{l}\text { MANOVA, comparison of new and veteran } \\
\text { caregivers }\end{array}$ & $\begin{array}{l}\text { Only a small amount of evidence exists for a } \\
\text { negative link between caregiving and } \\
\text { subjective well-being }\end{array}$ \\
\hline Legg et al. (2013) & $\begin{array}{l}\mathrm{N}=44,465,833, \mathrm{UK} \text { Census (2001, C, } \\
\text { including 5,451,902 caregivers) }\end{array}$ & Level of caregiving, caregiver demographics & $\begin{array}{l}\text { Caregivers providing more than } 20 \text { hours care } \\
\text { per week report lower levels of health }\end{array}$ \\
\hline O’Reilly et al. (2008) & $\begin{array}{l}\mathrm{N}=974,450 \text {, Northern Ireland Census (2001, } \\
\text { C) }\end{array}$ & Level of caregiving, caregiver demographics & $\begin{array}{l}\text { Caregivers show lower levels of mortality } \\
\text { than noncaregivers. The effect is especially } \\
\text { large for female, older, and generally sick } \\
\text { caregivers }\end{array}$ \\
\hline Raschick \& Ingersoll-Dayton (2004) & $\begin{array}{l}\text { N=978, National Long-Term Care } \\
\text { Survey(1999, C) }\end{array}$ & $\begin{array}{l}\text { Two-step hierarchical regression, care } \\
\text { recipient disabilities, relationship, caregiver } \\
\text { gender }\end{array}$ & $\begin{array}{l}\text { Women perceive more caregiving costs than } \\
\text { men, and adult children receive higher } \\
\text { emotional rewards than spouses }\end{array}$ \\
\hline Schulz \& Beach (1999) & $\begin{array}{l}\mathrm{N}=819 \text { aged } 66-96 \text { years for four US } \\
\text { communities }(1993-1998, \mathrm{~L})\end{array}$ & $\begin{array}{l}\text { Caregiver baseline health with a 4-year } \\
\text { follow-up, caregiver demographics }\end{array}$ & $\begin{array}{l}\text { Perceiving a high burden from caregiving in- } \\
\text { creases mortality risk }\end{array}$ \\
\hline
\end{tabular}

ADL = Activities of Daily Living, SEM = Structural Equation Model 
Table 3 Studies on Informal Care and Family

\begin{tabular}{|l|l|l|l|}
\hline Author & Data & Controls & Key results \\
\hline Brody et al. (1995) & $\begin{array}{l}\text { U.S. sample of 364 daughters sharing households with } \\
\text { their elderly parents }\end{array}$ & $\begin{array}{l}\text { ANOVA, linear regression, } \\
\text { caregiver and care receiver } \\
\text { characteristics. }\end{array}$ & $\begin{array}{l}\text { Married daughters fared best in well-being, which may } \\
\text { be related to higher income, social support, and more } \\
\text { helpers in caregiving. }\end{array}$ \\
\hline Litvin et al. (1995) & U.S. sample of 522 primary caregiving daughters & ANOVA & $\begin{array}{l}\text { Even though the family can support caregivers, } \\
\text { married women suffer most from competing demands } \\
\text { of caregiving }\end{array}$ \\
\hline Young \& Grundy (2008) & $\begin{array}{l}\text { N=110,464, UK Census data from the Office for } \\
\text { National Statistics Longitudinal Study (1981-2001, L) }\end{array}$ & Logit, caregiver characteristics & $\begin{array}{l}\text { Singles might be more likely to provide care because } \\
\text { of financially limited access to formal care. Women } \\
\text { showing lower attachment to the labor force after child } \\
\text { birth were more likely to become caregivers }\end{array}$ \\
\hline Pezzin \& Schone (1999) & $\begin{array}{l}424 \text { parent (60+)-daughter pairs from the Hebrew } \\
\text { Rehabilitation Center for the Aged (HRCA) Survey of } \\
\text { the Elderly and HRCA-NBER Child Survey (1986-87, } \\
\text { C) }\end{array}$ & $\begin{array}{l}\text { Maximum likelihood, parent } \\
\text { and child characteristics }\end{array}$ & $\begin{array}{l}\text { Children select into the caregiver and co-residing roles } \\
\text { based on opportunity costs: employment and } \\
\text { competing demands }\end{array}$ \\
\hline
\end{tabular}




\section{References}

Albertini, M., Kohli, M. \& Vogel, C. (2007). Intergenerational transfers of time and money in European families: common patterns—different regimes?' Journal of European Social Policy 17(4): 319-334.

Amirkhanyan, A. \& Wolf, D. (2006). Parent care and the stress process: Findings from panel data. Journals of Gerontology. Series B, Psychological Sciences and Social Sciences 61(5): S248-255.

Antonovics, K. \& Town, R. (2004). Are all the good men married? Uncovering the sources of the marital wage premium. American Economic Review 94(2): 317-321.

Arno, P. S., Levine, C. \& Memmott, M. M. (1999). The economic value of informal caregiving. Health Affairs 18(2): 182-188.

Ashworth, M. \& Baker, A. H. (2000). “Time and space”: Carers’ views about respite care. Health \& Social Care in the Community 8(1): 50-56.

Becker, G. (1965). A theory of the allocation of time. Economic Journal 75(299): 493517.

Bell, D., Otterbach, S. \& Sousa-Poza, A. (2012). Work hours constraints and health. Annals of Economics and Statistics 105-106: 33-55.

Berecki-Gisolf, J., Lucke, J., Hockey, R. \& Dobson, A. (2008). Transitions into informal caregiving and out of paid employment of women in their 50s. Social Science \& Medicine 67(1): 122-127.

Bettio, F. \& Verashchagina, A. (2010). Long-term care for the elderly: Provisions and providers in 33 European countries. EU Expert Group on Gender and Employment, Luxembourg.

Bittman, M., Hill, T. \& Thomas, C. (2007). The impact of caring on informal carers' employment, income and earnings: A longitudinal approach. Australian Journal of Social Issues 42(2): 255-272.

Black, W. \& Almeida, O. (2004). A systematic review of the association between the behavioral and psychological symptoms of dementia and burden of care. International Psychogeriatrics 16(3): 295-315.

Bobinac, A., Van Exel, N. J. A., Rutten, F. F. H. \& Brouwer, W. B. F. (2010). Caring for and caring about: Disentangling the caregiver effect and the family effect. Journal of Health Economics 29(4): 549-556. 
Bolin, K., Lindgren, B. \& Lundborg, P. (2008a). Informal and formal care among single-living elderly in Europe. Health Economics 17(3): 393-409.

Bolin, K., Lindgren, B., \& Lundborg, P. (2008b). Your next of kin or your own career? Caring and working among the 50+ of Europe. Journal of Health Economics 27(3): 718-738.

Bonsang, E. (2009). Does informal care from children to their elderly parents substitute for formal care in Europe? Journal of Health Economics 28(1): 143-154.

Bookwala, J. (2009). The impact of parent care on marital quality and well-being in adult daughters and sons. Journals of Gerontology. Series B, Psychological Sciences and Social Sciences 64(3): 339-347.

Brickman, P. \& Campbell, D. T. (1971). Hedonic relativism and planning the good society. In M.H. Apley (Ed.), Adaptation Level Theory: A Symposium, (pp. 287-302). New York: Academic Press.

Brody, E. M., Litvin, S. J., Hoffman, C. \& Kleban, M. H. (1995) Marital status of caregiving daughters and co-residence with dependent parents. Gerontologist 35(1): 75-85.

Brown, J., Demou, E., Tristram, M. A., Gilmour, H., Sanati, K. A. \& Macdonald, E. B. (2012). Employment status and health: understanding the health of the economically inactive population in Scotland. BMC Public Health 12(327): 1-9.

Brown, S. L., Nesse, R. M., Vinokur, A. D. \& Smith, D. M. (2003). Providing social support may be more beneficial than receiving it: Results from a prospective study of mortality. Psychological Science 14(4): 320-327.

Bureau of Labour Statistics (Eds.) (2013). Unpaid eldercare in the United States, 2011-2012: Data from the American Time Use Survey. Washington, DC: United States Bureau of Labor Statistics.

Carmichael, F. \& Charles, S. (2003). The opportunity costs of informal care: Does gender matter? Journal of Health Economics 22(5): 781-803.

Carmichael, F., Charles, S. \& Hulme, C. (2010). Who will care? Employment participation and willingness to supply informal care. Journal of Health Economics 29(1): 182-190.

Carmichael, F., Hulme, C., Sheppard, S. \& Connell, G. (2008). Work-life imbalance: Informal care and paid employment in the UK. Feminist Economics 14(2): 3-35.

Casado-Marin, D., Gracia Gomez, P. \& Lopez Nicolas, A. (2011). Informal care and labour force 
participation among middle-aged women in Spain. SERIEs 2(1): 1-29.

Chappell, N. L. \& Reid, R. C. (2002). Burden and well-being among caregivers: Examining the distinction. Gerontologist 42(6): 772-780.

Ciani, E. (2012). Informal adult care and caregiver’s employment in Europe. Labour Economics 19(2): 155-194.

Clark, R. E., Xie, H., Adachi-Mejia, A. M. \& Sengupta, A. (2001). Substitution between formal and informal care for persons with severe mental illness and substance use disorders. Journal of Mental Health Policy and Economics 4(3): 123-132.

Coe, N. \& Van Houtven, C. (2009). Caring for Mom and neglecting yourself? The health effects of caring for an elderly parent. Health Economics 18(9): 991-1010.

Cohen, C. A., Colantonio, A., \& Vernich, L. (2002). Positive aspects of caregiving: Rounding out the caregiver experience. International Journal of Geriatric Psychiatry 17: 184-188.

Cooper C., Balamurali, T. B. S. \& Livingston, G. (2007). A systematic review of the prevalence and covariates of anxiety in caregivers of people with dementia. International Psychogeriatrics 19(2): $175-195$

Dautzenberg, M., Diederiks, J., Philipsen, H., Stevens, F., Tan, F. \& Vernooij-Dassen, M. (2000). The competing demands of paid work and parent care: Middle-aged daughters providing assistance to elderly parents. Research on Aging 67(2): 165-187.

Dujardin, C., Farfan-Portet, M.-I., Mitchell, R., Popham, F., Thomas, I. \& Lorant, V. (2011). Does country influence the health burden of informal care? An international comparison between Belgium and Great Britain. Social Science \& Medicine 73(8): 1123-1132.

Etters, L., Goodall, D. \& Harrison, B. E. (2008). Caregiver burden among dementia patient caregivers: A review of the literature. Journal of the American Academy of Nurse Practitioners 20(8): 423428.

European Commission (Eds.) (2011). Strategy for equality between women and men 2010-2015. EC, Luxembourg. 
Farfan-Portet, M.-I., Popham, F., Mitchell, R., Swine, C. \& Lorant, V. (2009). Caring, employment and health among adults of working age: Evidence from Britain and Belgium. European Journal of Public Health 20(1): 52-57.

Gautun, H. \& Hagen K. (2010). How do middle-aged employees combine work with caring for elderly parents? Community, Work \& Family 13(4): 393-409.

Gräsel, E. (2002). When home care ends_changes in the physical health of informal caregivers caring for dementia patients: A longitudinal study. Journal of the American Geriatrics Society 50(5): 843849.

Gronan, R. (1977). Leisure, home production and work the theory of the allocation of time revisited. Journal of Political Economy 85(8), 1099-1123.

Hassink, W. H. J. \& Van den Berg, B. (2011). Time-bound opportunity costs of informal care: Consequences for access to professional care, caregiver support, and labour supply estimates. Social Science \& Medicine 74(10): 1508-1516.

Heitmueller, A. (2007). The chicken or the egg? Endogeneity in labour market participation of informal carers in England. Journal of Health Economics 26(3): 536-559.

Heitmueller, A. \& Inglis, K. (2007). The earnings of informal care: Wage differentials and opportunity costs. Journal of Health Economics 26(4): 821-841.

Helmert, U. \& Shea, S. (1998). Family status and self-reported health in West Germany. Sozial-und Präventivmedizin 43(3): 124-132.

Hirst, M. (2005). Carer distress: A prospective, population-based study. Social Science \& Medicine 61(3): 697-708.

Jiménez-Martín, S. \& Prieto, C. V. (2012). The trade-off between formal and informal care in Spain. European Journal of Health Economics 13(4): 461-490.

Johnson, R. \& Lo Sasso, A. (2006).The impact of elder care on women’s labor supply. Inquiry 43: $195-210$.

Keating, N. C., Fast, J. E., Lero, D. S., Lucas, S. L. \& Eales, J. (2014). A taxonomy of the economic costs of family care to adults. Journal of the Economics of Ageing 3, 11-20. 
Kemper, P., Komisar, H. L. \& Alecxih, L. (2005). Long-term care over an uncertain future: What can current retirees expect? Inquiry 42(4): 335-350.

King, D. \& Pickard, L. (2013). When is a carer's employment at risk? Longitudinal analysis of unpaid care and employment in midlife in England. Health \& Social Care in the Community 21(3): 303314.

Kotsadam, A. (2011). Does informal eldercare impede women’s employment? The case of European welfare states. Feminist Economics 17(2): 121-144.

Langa, K. M., Chernew, M. E., Kabeto, M. U., Herzog, A. R., Ofstedal, M. B., Willis, R. J., Wallace, R. B., Mucha, L. M., Straus, W. L. \& Fendrick, A. M. (2001). National estimates of the quantity and cost of informal caregiving for the elderly with dementia. Journal of General Internal Medicine 16(11): 770-778.

Lawton, M. P., Moss, M., Hoffman, C. \& Perkinson, M. (2000). Two transitions in daughters' caregiving careers. Gerontologist 40(4): 437-448.

Lee, Y. \& Tang, F. (2013). More caregiving, less working: Caregiving roles and gender difference. Journal of Applied Gerontology (in press).

Legg, L., Weir, C. J., Langhorne, P., Smith, L. N., \& Stott, D. J. (2013). Is informal care giving independently associated with poor health? A population-based study. Journal of Epidemiology and Community Health 67(1): 95-97.

Leigh, A. (2010). Informal care and labor market participation. Labour Economics 17(1): 140 149.

Lilly, M., Laporte, A. \& Coyte, P. C. (2007). Labor market work and home care’s unpaid caregivers: A systematic review of labor force participation rates, predictors of labor market withdrawal, and hours of work. Milbank Quarterly 95 (4): 641-690.

Lilly, M., Laporte, A. \& Coyte, P. C. (2010). Do they care too much to work? The influence of caregiving intensity on the labour force participation of unpaid caregivers in Canada. Journal of Health Economics 29(6): 895-903.

Lim, J. \& Zebrack, B. (2004). Caring for family members with chronic physical illness: A critical review of caregiver literature. Health and Quality of Life Outcomes 2: 50. 
Litvin, S. J., Albert, S. M., Brody, E. M. \& Hoffman, C. (1995). Marital status, competing demands, and role priorities of parent-caring daughters. Journal of Applied Gerontology 14(4): 372-390.

Meng, A. (2012). Informal home care and labor force participation of house hold members. Empirical Economics 44(2): 959-979.

Mentzakis, E., McNamee, P. \& Ryan, M. (2009). Who cares and how much: Exploring the determinants of co-residential informal care. Review of Economics of the Household 7(3): 283-303.

Michaud, P. C., Heitmueller, A. \& Nazarov, Z. (2010). A dynamic analysis of informal care and employment in England. Labour Economics 17(3): 455-465.

Moscarola, F. C. (2010). Informal caregiving and women’s work choices: Lessons from the Netherlands. Labour 24(1): 93-105.

Nguyen, H. T. \& Connelly L. B. (2014). The effect of unpaid caregiving intensity on labour force participation: Results from a multinomial endogenous treatment model. Social Science \& Medicine 100: $1145-1122$.

OECD (Eds.) (2011). Help wanted? Providing and paying for long-term care. EC, Paris.

O’Reilly, D., Connolly, S., Rosato, M. \& Patterson, C. (2008). Is caring associated with an increased risk of mortality? A longitudinal study. Social Science \& Medicine 67(8): 1282-1290.

Pavalko, E. K. \& Henderson, K. A. (2006). Combining care work and paid work: Do workplace policies make a difference? Research on Aging 28(3): 359-374.

Pezzin, L. E., Kemper, P. \& Reschovsky, J. (1996). Does publicly provided home care substitute for family care? Experimental evidence with endogenous living arrangements. Journal of Human Resources 31(3): 650-676.

Pezzin, L. \& Schone, B. (1999). Intergenerational household formation, female labor supply and informal caregiving: a bargaining approach. Journal of Human Resources 34(3): 475-503.

Pickard, L. (2012). Substitution between formal and informal care: A "natural experiment” in social policy in Britain between 1985 and 2000. Ageing and Society 32(7): 1147-1175.

Pinquart, M. \& Sörensen, S. (2003a). Associations of stressors and uplifts of caregiving with caregiver burden and depressive mood: A meta-analysis. Journals of Gerontology. Series B, Psychological Sciences and Social Sciences 58(2): 112-128. 
Pinquart, M. \& Sörensen, S. (2003b). Differences between caregivers and noncaregivers in psychological health and physical health: A meta-analysis. Psychology and Aging 18(2): 250-267.

Pinquart, M. \& Sörensen, S. (2006). Gender differences in caregiver stressors, social resources, and health: An updated meta-analysis. Journals of Gerontology. Series B, Psychological Sciences and Social Sciences 61(1): 33-45.

Pinquart, M. \& Sörensen, S. (2007). Correlates of physical health of informal caregivers: A metaanalysis. Journals of Gerontology. Series B, Psychological Sciences and Social Sciences 62(2): $126-137$.

Polder, J. J., Bonneux, L., Meerding, W. J. \& Van der Maas, P. J. (2002). Age-specific increases in health care costs. European Journal of Public Health 12(1): 57-62.

Raschick, M. \& Ingersoll-Dayton, B. (2004). The costs and rewards of caregiving among aging spouses and adult children. Family Relations 53(3): 317-325.

Reid, R. C., Stajduhar, K. I. \& Chappell, N. L. (2010). The impact of work interferences on family caregiver outcomes. Journal of Applied Gerontology 29(3): 267-289.

Satariano, W. A., Minkler, M. A. \& Langhauser, C. (1984). The significance of an ill spouse for assessing health differences in an elderly population. Journal of the American Geriatric Society 32(3): 187-190.

Savage, S. \& Bailey, S. (2004). The impact of caring on caregivers' mental health: A review of the literature. Australian Health Review 27(1): 111-117.

Schmitz, H. \& Stroka, M. A. (2013). Health and the double burden of full-time work and informal care provision: Evidence from administrative data. Labour Economics 24: 305-322.

Schneider, U. (2006). Informelle Pflege aus ökonomischer Sicht [Informal care from an economic perspective]. Zeitschrift für Sozialreform 52(4): 493-520.

Schoenmakers, B., Buntinx, F. \& Delepeleire, J. (2010). Factors determining the impact of care-giving on caregivers of elderly patients with dementia. A systematic literature review. Maturitas 66(2): 191-200.

Schulz, R. \& Beach, S. (1999). Caregiving as a risk factor for mortality. Journal of the American Medical 282(23): 2215-2219. 
Schulz, R., O’Brien, A. T., Bookwala, J. \& Fleissner, K. (1995). Psychiatric and physical morbidity effects of dementia caregiving: prevalence, correlates, and causes. Gerontologist 35(6): 771-791.

Schulz, R., Visintainer, P. \& Williamson, G. M. (1990). Psychiatric and physical morbidity effects of caregiving. Journal of Gerontology 45(5): 181-191.

Schwarzkopf, L., Menn, P., Leidl, R., Wunder, S., Mehlig, H., Marx, P., Graessel, E. \& Holle, R. (2012). Excess costs of dementia disorders and the role of age and gender: An analysis of German health and long-term care insurance claims data. Health Services Research 12(165): 1-12.

Sousa-Poza, A., Schmid, H. \& Widmer, R. (2001). The allocation and value of time assigned to housework and child-care: An analysis for Switzerland. Journal of Population Economics 14(4): 599-618.

Spiess, C. K. \& Schneider, U. (2003). Interactions between care-giving and paid work hours among European midlife women, 1994 to 1996. Ageing and Society 23(1): 41-68.

Triantafillou, J., Naiditch, M., Repkova, K., Stiehr, K., Carretero, S., Emilsson, T., Di Santo, P., Bednarik, R., Brichtova, L., Ceruzzi, F., Cordero, L., Mastroyiannakis, T., Ferrando, M., Mingot, K., Ritter, J. \& Vlantoni, D. (2010). Informal care in the long-term care system. Interlinks European Overview Paper, Athens/Vienna.

Ugreninov, E. (2013). Offspring in squeeze: Health and sick leave absence among middle-aged informal caregivers. Journal of Population Ageing 6(4): 323-338.

Van den Berg, B., Al, M., Brouwer, W., Van Exel, J. \& Koopmanschap, M. (2005). Economic valuation of informal care: The conjoint measurement method applied to informal caregiving. Social Science \& Medicine 61(6): 1342-1355.

Van den Berg, B., Brouwer, W. B. F. \& Koopmanschap, M. A. (2004). Economic valuation of informal care: An overview of methods and applications. European Journal of Health Economics 5(1): 36-45.

Van den Berg, B. \& Ferrer-i Carbonell, A. (2007). Monetary valuation of informal care: The wellbeing valuation method. Health Economics 16: 1227-1244.

Van den Berg, B. \& Spauwen, P. (2006). Measurement of informal care: An empirical study into the valid measurement of time spent on informal caregiving. Health Economics 15(5): 447- 
460.

Van Houtven, C. H., Coe, N. B. \& Skira, M. M. (2013). The effect of informal care on work and wages. Journal of Health Economics 32(1): 240-252.

Van Houtven, C. H. \& Norton, E. C. (2004). Informal care and health care use of older adults. Journal of Health Economics 23(6): 1159-1180.

Viitanen T. (2010). Informal eldercare across Europe: Estimates from the European Community Household Panel. Economic Analysis and Policy 40(2): 149-178.

Vitaliano, P., P., Zhang, J. \& Scanlan, J. M. (2003). Is caregiving hazardous to one’s physical health? A meta-analysis. Psychological Bulletin 129(6): 946-972.

Vlachantoni, A., Evandrou, M., Falkingham, J. \& Robards, J. (2012). Informal care, health and mortality. Maturitas 72(2): 114-118.

Wakabayashi, C. \& Donato, K. M. (2005). Population research and policy review. Population Research and Policy Review 24(5): 467-488.

Yee, J. L. \& Schulz, R. (2000). Gender differences in psychiatric morbidity among family caregivers: A review and analysis. Gerontologist 40(6): 643-644.

Young, H. \& Grundy, E. (2008). Longitudinal perspectives on caregiving, employment history and marital status in midlife in England and Wales. Health \& Social Care in the Community 16(4): 388399. 